\title{
Stigma and Stratification Limiting the Math Course Progression of Adolescents Labeled with a Learning Disability
}

\begin{abstract}
Learning disability (LD) designations may produce stigma by masking the real causes of learning differences, altering perceptions, and legitimizing stratification. This study uses data on adolescents and their teachers from The Education Longitudinal Study of 2002 to show the negative effect of LD designations on adolescents' math course attainment is partially mediated by disparities in adolescents' earlier math course placements, and teachers' more negative attributions and expectations. Results indicate addressing low achievement through LD designations may reproduce disadvantage through stigma and stratification.
\end{abstract}

Keywords: teacher expectations, educational stratification, special education, labeling, learning disabilities, mathematics 


\section{Stigma and Stratification Limiting the Math Course Progression of Adolescents Labeled with a Learning Disability}

\section{Introduction}

Some disability categories, such as autism and attention deficit hyperactivity disorder (ADHD), are perceived as a means of securing extra educational resources (King, Jennings, \& Fletcher, 2014), perhaps because they are more prevalent among white or socially advantaged youth in the US (Eyal, 2013; King \& Bearman, 2011; Morgan, Staff, Hillemeier, Farkas, \& Maczuga, 2013). In contrast, racial minorities and poor youth are disproportionately classified with learning disabilities (LDs) in both the US and Europe (Ong-Dean, 2009; Strand \& Lindsay, 2009). Comprising the largest proportion (nearly half) of the special education population in the US in 2003 (Spellings, Knudsen, \& Guard, 2007), LDs include disorders like dyslexia, dyscalculia, and dysgraphia, that is, issues respectively with reading, calculation, and writing (American Psychiatric Association, 2000). In an important clarification, 'learning difficulty' describes British students that might be described as learning disabled in America, whereas the British use 'learning disability' to describe youth with low IQs (Jingree \& Finlay, 2012). Youth with low IQs are also categorized separately from youth with LDs in the US but are described as intellectually disabled' (formerly 'mentally retarded').

Youth labeled with LDs fare poorly on a multitude of life outcomes, including math outcomes (Shifrer, Callahan, \& Muller, 2013). Students classified with an LD typically struggle in math coursework regardless of the specific diagnosis (e.g., dyslexia, dyscalculia) (Krajewsi \& Schneider, 2009), as math coursework involves reading and writing as well as calculation. The common attribution of this group's poorer outcomes to neurological 
differences is problematic given the subjective socially rooted diagnostic criteria (Devine, Soltész, Nobes, Goswami, \& Szúcs, 2013). The possibility that these students' poorer outcomes partially result from stigma and stratification related to the LD designation is particularly troubling given the disproportionate categorization of poor youth and racial minorities with LDs, and evidence that classifications sometimes occur inaccurately or inequitably (Samson \& Lesaux, 2009; Shifrer, Muller, \& Callahan, 2011).

This study uses data from the Education Longitudinal Study of 2002 (ELS), a large data set representative of $10^{\text {th }}$ graders in the US in 2002 , to investigate whether stigma is implicated in the high school math course attainment of adolescents designated with an LD. Multilevel models first investigate differences by LD status in teachers' attributions of academic performance to disability, teachers' educational attainment expectations for adolescents, and adolescents' early high school math progression. A decomposition technique then demonstrates the degree to which any disparities in these early high school outcomes contribute to designated adolescents' lower math course attainment by the end of high school. This study is an important contribution because of its use of data with individual level measures, a large and diverse sample, and inclusion of peers not designated with disability as a base of comparison. The few research teams using individual level data representative of the US population find youth designated with an LD underperform even compared to otherwise similar youth without a disability designation (Morgan, Frisco, Farkas, \& Hibel, 2010; Shifrer et al., 2013), but have not identified processes within schools that contribute to these disparities. This study moves beyond the documentation of gaps in search of specific mechanisms whereby LD designations influence poorer outcomes. ELS also measures the official school designation of disability, 
whereas previous studies relied on adolescents' or their parents' perceptions of disability, or even diagnosed adolescents through a survey, such as Sprung et al. (2009). This study focuses on teachers' expectations for adolescents' educational attainment, a contribution to the previous expectancy literature that has largely focused on teachers' expectations for performance in the classroom (Eccles \& Wigfield, 1985; Good, Aronson, \& Inzlicht, 2003; Jussim, Smith, Madon, \& Palumbo, 1998; Rubie-Davies, 2006). In addition to being relevant for educational policy related to low achievement and the professional development of teachers, this study's findings contribute to the literatures on educational stratification, educational psychology, labels, stigma, and educational disabilities.

\subsection{Stigma}

Link and Phelan (2001) framed stigma as powerful entities allowing labeling, stereotyping, and separation to culminate in status loss and discrimination, as evidenced in poorer outcomes in important life domains. Progression through high school math coursework, closely linked with success in other academic subjects and enrollment in college (Hudson \& O'Rear, 2015; McFarland, 2006), is an important life outcome for adolescents. Hypothesis 1: If the lower math course attainment of adolescents is partially a function of stigma and stratification, measures of labeling, stereotyping, and separation will explain some part of the negative association between the LD designation and math course attainment, net of controls for adolescents' social and academic backgrounds, and attitudes and behaviors.

\subsection{Labeling: Teachers' attributions}

Beginning with the labeling component of stigma, Link and Phelan (2001) describe how differences first gain salience through oversimplification and inconsistency in the 
qualities that qualify a person for inclusion in the group. The adolescents in this study were likely diagnosed by school personnel through one of three models, as described by Fletcher, Denton, and Francis (2005). In the ability-achievement discrepancy model, adolescents receive the LD designation for achievement levels lower than expected given their IQ. In the intra-individual discrepancy model, an uneven cognitive profile, strengths in some areas and weaknesses in others, suggests an LD. The low-achievement model legitimized the classification of any student unexpectedly performing below a certain benchmark. With LD diagnostic practices contextually variable (Lester \& Kelman, 1997), the qualities of students classified with an LD are inconsistent (Singer, Palfrey, Butler, \& Walker, 1989) and not easily distinguished from those of unclassified low achievers (Fletcher et al., 2005).

LD diagnostic criteria, primarily academic achievement and, to a lesser extent, learning behaviors (Hibel, Farkas, \& Morgan, 2010), are also socially rooted and subjective. Both are socially rooted because they vary as a function of economic status and culture (McLeod \& Kaiser, 2004; Noguera, 2003). Importantly, subjectivity may facilitate bias but is not always indicative of biased designations. For instance, whereas there are relatively objective indicators of achievement, teachers may unconsciously shift the bar for a special education referral depending on the average achievement level of the other students in the school (Hibel et al., 2010). Ultimately, although the LD classification may represent valid neurological or biological distinctions, the categorization occurs without explicit confirmation of such difference (Vellutino, Fletcher, Snowling, \& Scanlon, 2004). America's federal regulations prohibit the designation of adolescents whose learning difficulties arise from "cultural factors," "economic disadvantage," or "Limited English proficiency" 
(Spellings et al., 2007), but it remains unclear whether diagnostic methods can make these distinctions, or if there even are valid distinctions (Dudley-Marling, 2004).

Building on previous studies' use of attributions to understand stigma (Phelan, 2005), teachers can attribute differences in student performance and behaviors to a multitude of factors other than disability, such as home life or poor attitudes. LDs are not associated with recognizable mannerisms or traits (Coughlin, 1997). Thus, among similarly achieving and behaving students, teachers' attributions of performance to disability could particularly depend on extra-classroom information they regard as important and objective. Carrier (1983) described the designation of a child as learning disabled as a process in which an explanation for a child's underachievement is developed and propagated. Hypothesis 2: If teachers interpret the school LD designation as an important objective indicator, they would be more likely to attribute the performance of an adolescent with an LD designation to disability than they are the performance of a similarly achieving and behaving adolescent not designated with disability.

\subsection{Negative stereotypes: Teachers' educational attainment expectations}

The linking of negative stereotypes to designated differences is the second element of stigma (Link \& Phelan, 2001). Although not focused on students classified with disability, previous studies consistently find student performance is partially a function of teachers' educational attainment expectations, even after accounting for the student qualities that shape teachers' educational attainment expectations (Becker, 2013; Benner \& Mistry, 2007; Gill \& Reynolds, 1999; Mistry, White, Benner, \& Huynh, 2009; Sciarra \& Ambrosino, 2011; Wu \& Bai, 2015). Teachers' expectations for students' performance within the classroom are largely accurate but can affect student performance net of prior 
performance (Good, 1981; Jussim, 1989; Jussim \& Eccles, 1992; Kaiser, Retelsdorf, Südkamp, \& Möller, 2013). The negative influence of teachers' expectations within the classroom on student performance is stronger for low-achieving students (Madon, Jussim, \& Eccles, 1997), and for students from lower income households (Sorhagen, 2013), qualities more prevalent among students classified with LDs (Shifrer et al., 2011; Wagner, Newman, Cameto, \& Levine, 2006). Qualitative studies found educators perceived children with disability designations in vignettes and videos more negatively than they did undesignated but similarly behaving children (Allday, Duhon, Blackburn-Ellis, \& Dycke, 2011; Ohan, Visser, Strain, \& Allen, 2011). If teachers interpret the LD designation as an indicator of biological difference despite the designation's social rootedness and subjectivity, stereotypes linked to the LD designation may trump more objective evidence. Hypothesis 3: Teachers' educational attainment expectations are, in themselves, not a stereotype, but if LD designations are negatively stereotyped, teachers will hold lower educational attainment expectations for adolescents designated with an LD than they do for similarly achieving and behaving adolescents without a disability designation.

\subsection{Separation: Early high school math progression}

Finally, conferring stigma requires the power to separate, or to control access to major life domains (Link \& Phelan, 2001). Although initially educated in separate schools and then in separate classrooms within regular schools (Office of Special Education Programs, n.d.), US youth designated with more mild disabilities, like LDs, are now largely mainstreamed into the same classrooms as their undesignated peers (Spellings et al., 2007). Nonetheless, even undesignated low-achievers experience some degree of stratification within schools (Gamoran \& Mare, 1989; Oakes, 1985/2009), and designated 
adolescents may experience even more as a result of stigma related to their LD designations. This study's focus on high school math, a hierarchically structured subject in the US, facilitates the identification of inequities, with adolescents typically progressing from Algebra I, Geometry, Algebra II, and then to higher level courses (Schneider, Swanson, \& Riegle-Crumb, 1998). Hypothesis 4: If the LD designation results in separation, adolescents designated with an LD should be less likely to experience progression in their $10^{\text {th }}$ grade math course placement than undesignated adolescents who achieved similarly in a comparable level of math during the $9^{\text {th }}$ grade.

\subsection{Potential confounders}

With earlier versions of labeling theory criticized for casting mental disorders as entirely the result of labeling effects, Link, Cullen, Struening, Shrout, and Dohrenwend (1989) advanced a modified labeling theory which argued labels can have negative effects even if labeled persons' poorer outcomes are not entirely attributable to the label. Thus, to isolate potential stigma, it is important to account for other differences between designated and undesignated adolescents that may influence teachers' perceptions and adolescents' math course progression. A previous study using nationally representative data showed youth designated with LDs begin high school in lower levels of math (Shifrer et al., 2011). Designated adolescents may progress less far in math than even similarly placed undesignated adolescents because of their lower average levels of performance and their more negative attitudes and behaviors (Lackaye \& Margalit, 2006). Finally, adolescents who expect to attend college in America are more likely to take higher level math courses in order to fulfill college admission requirements (Adelman, 2006). This study employs a wealth of measures to narrow the focus on how stigma and stratification may influence the 
course progression of designated adolescents relative to undesignated adolescents with similar social and academic backgrounds, comparable levels of performance in math during early high school, and similar attitudes and behaviors.

\subsection{Present study}

The present study investigates whether stigma is implicated in the high school math course attainment of adolescents designated with an LD. First, multilevel models, with powerful controls for differences in designated and undesignated adolescents' backgrounds, achievement, attitudes and behaviors, explore disparities by LD status in teachers' attributions of academic performance to disability (labeling, Hypothesis 2), educational attainment expectations (stereotyping, Hypothesis 3), and adolescents' early high school math progression (separation, Hypothesis 4). Finally, a decomposition technique demonstrates the degree to which any disparities in these early high school outcomes contribute to designated adolescents' lower math course attainment by the end of high school (Hypothesis 1). This technique establishes direct links between the LD designation, measured correlates of the LD designation, and outcomes shown to be impacted by the LD designation, while accounting for other differences between designated and undesignated adolescents.

\section{Method}

The National Center for Education Statistics (NCES) first surveyed 16,373 10th graders enrolled in approximately 750 schools in the US in 2002 for ELS. This study uses data from the base year (2002, when adolescents were in grade ten) surveys of adolescents, a parent, and adolescents' $10^{\text {th }}$ grade English and math teachers (the only teachers surveyed by NCES). NCES administered a standardized math test during the base 
year, and collected transcript data for approximately $91 \%$ of the student sample once most students had completed high school (National Center for Education Statistics, 2010). After excluding adolescents designated with a disability other than an LD (about 300), or who attended a school that did not report sampled students' disability statuses $(n=3750)$ (more details below), this study's analytic sample includes about 10,790 adolescents in 540 schools.

\subsection{Learning disability designation}

Schools reported which sampled students were in receipt of special education services during the tenth grade and their qualifying federal disability category. This study focuses on adolescents receiving special education services through the LD category (American Psychiatric Association, 2000). In the US, this federal disability category includes students with disorders related to language, reading (dyslexia), writing (dysgraphia), or calculation (dyscalculia) (https://sped.dpi.wi.gov/sped_ldcriter); the data do not specify the student's specific LD. As stated in the review of the literature, these students were classified with any one of three dominant diagnostic models, depending on school districts' interpretations of US federal guidelines. In the US, adolescents with conditions like intellectual disabilities, ADHD, Down syndrome, and autism qualify for special education services under disability categories other than the LD category and are excluded from this study.

Aligning with national benchmarks (Spellings et al., 2007), approximately 690 of the adolescents in the analytic sample (6\%) are designated with an LD by their school. For reasons that remain unclear (even after contacting NCES), schools did not report the special education status of about 8,210 students. Aggregation to the school level 
demonstrated that special education reports were available for no sampled students in 202 schools, some sampled students in 212 schools, and all sampled students in 334 schools. Comparable mean proportions of students were designated with an LD (and with any disability) across the two groups of schools reporting the special education statuses of all and only some of their sampled students. For these reasons, the 4,000 students without a special education status, who attended schools that reported the special education status of some sampled students, are classified as not designated with disability in this study. This study only excludes the 3,750 students in schools that reported the special education statuses of no sampled students.

Adolescents excluded from the analytic sample were more likely to be racial minorities and had higher average socioeconomic status (SES) (Online Table 1). Although findings were mixed, excluded adolescents generally exhibited higher levels of achievement, and more positive attitudes and behaviors, than adolescents in the analytic sample. Excluded adolescents' relative advantages may suggest the results of this study are only conservative estimates. Results from additional sensitivity analyses are discussed in the limitations section. Ultimately, this study's analytic sample cannot be described as representative of the US population of $10^{\text {th }}$ graders in 2002 because of distinctions between included and excluded adolescents. Nonetheless, this study's findings are still an important contribution because the analytic sample remains large and diverse, and there is currently no other datasets in the US with measures comparable to those available in ELS.

Parents could also choose 'Specific learning disabilities' in response to "In your opinion, which of these disabilities does your tenth grader have?" This measure is not incorporated into analyses because: 1) parent reports may be less likely than school 
designations to be based on a formal diagnosis (Ong-Dean, 2009), 2) exploratory analyses showed students' math outcomes and teachers' attributions and expectations were informed by the school designation to a much greater degree than by parent disability reports, and 3) including multiple reports needlessly increased the complexity of results. Shifrer (2013) used ELS and similarly found school disability designations appeared to have much more social salience than parent reports.

\subsection{Math course attainment by the end of high school}

This study's primary dependent variable, highest math course attempted by the end of high school, includes courses adolescents did not pass in order to differentiate access from performance. This measure has five categories: lower than Algebra I, Algebra I,

Geometry, Algebra II, and higher than Algebra II. The small number of adolescents who did not progress beyond special education math coursework or who attempted no math coursework by the end of high school are included in the lowest category.

\subsection{Labeling, stereotyping, and separation}

Labeling, stereotyping, and separation, that is, potential indicators of stigma, are measured respectively by teachers' attributions of student performance to disability, teachers' educational attainment expectations, and each adolescent's level of $10^{\text {th }}$ grade math coursework. Importantly, baseline differences by LD designation status in these early high school outcomes are not considered indicative of stigma because of the influence of systematic differences between designated and undesignated adolescents. Rather, this study conceptualizes disparities by LD designation status that persist net of controls for adolescents' earlier achievement, attitudes, and behaviors as potentially indicative of separation, labeling, and stereotyping. These measures are conceptualized as mediators 
under the assumption that the vast majority of designated adolescents in this sample were initially designated with an LD well before high school, with the median age of designation five years old (Ong-Dean, 2009).

Labeling. First, a dichotomous measure indicates whether $10^{\text {th }}$ graders' math teachers attribute their performance to disability, that is, whether the teacher responded affirmatively to this survey question: "In your opinion, does this adolescent have a learning-, physical-, or emotional- disability that affects his/her school work?" The purposes of this study would have been better served if teachers were asked specifically about LDs, but this issue is partially ameliorated by the exclusion of adolescents designated by their school with a disability other than an LD. The school LD classification, a marker of difference, does not function as a label unless teachers perceive it as important and objective enough to attribute the student's performance at least in part to disability. Alternatively, a teacher who does not perceive school LD classifications as objective or important might disregard students' special education files or might feel the classification inaccurately captures the students' salient differences, in which case the teachers would not attribute the students' performance to disability. This study is also limited by the possibility that teachers might have responded in the positive to this question, thinking of a disability other than an LD, despite a school LD classification.

Stereotyping. Second, a dichotomous measure indicates whether math teachers reported they expected at least a Bachelor's degree for the adolescents they taught during the $10^{\text {th }}$ grade. Teachers' expectations in themselves are not stereotypes. Rather, teachers' lower expectations for students designated with an LD, net of the students' background, achievement, and behaviors, may indicate stereotyped expectations, in that the educational 
attainment expectations appear to be informed at least in part by the teachers' general beliefs about disability. Results were similar with an ordinal version of teachers' educational attainment expectations (1=Less than high school graduation, $2=$ High school graduation or GED only, 3=Attend or complete 2-year college, 4=Attend college, 4-year degree incomplete, 5=Graduate from college, 6=0btain Master's degree or equivalent, 7=Obtain $\mathrm{PhD}, \mathrm{MD}$, other advanced degree) but a dichotomous version of this variable streamlined analyses.

Separation. Third, differences in course progression are captured by a dichotomous measure of whether the level of each adolescent's $10^{\text {th }}$ grade math course is higher than the level of their $9^{\text {th }}$ grade math course. In the US, student choice plays a very small role in math-course taking, particularly in the earliest years of high school. Math is typically a required course and the vast majority progress through the same hierarchical sequence of courses (Algebra I, Geometry, Algebra II, Pre-Calculus). With each course a prerequisite for the next course, $9^{\text {th }}$ grade placement is largely a function of the level of the student's $8^{\text {th }}$ grade course, and so on through the years. For these reasons, this study compares designated students' odds of progressing in their $10^{\text {th }}$ grade math course placement to that of undesignated adolescents who performed comparably in a similar level of $9^{\text {th }}$ grade math. Analyses focus on the $9^{\text {th }}$ to $10^{\text {th }}$ grade transition, because the $10^{\text {th }}$ grade is a pivotal year for math progression in the US (Gamoran, Porter, Smithson, \& White, 1997), and because NCES collected the most data on math experiences during the base year. The $4 \%$ of adolescents who did not take math during the $9^{\text {th }}$ grade are classified as having progressed, and the $3 \%$ of adolescents who did not take math during the $10^{\text {th }}$ grade are classified as having not progressed. In addition to these students numbering too few to 
analytically separate, the normativity of taking math in the $9^{\text {th }}$ and $10^{\text {th }}$ grades in the US supports the inclusion of these students in the progress conceptualization. The small number of adolescents in math coursework higher than Algebra II in both the $9^{\text {th }}$ and $10^{\text {th }}$ grades are classified as having progressed.

\subsection{Controls}

With all controls from data collected during the base year, a first set focuses on sociodemographic and academic background, or more specifically, each adolescent's gender, race, SES, household cognitive resources, family structure, parents' educational attainment expectations, history in remedial math or English, history of grade retention, and age. ELS' SES composite summarizes parent reports of family income, each parent's occupation, and each parent's educational attainment. The cognitive resources scale sums adolescents' reports of items present in their household: daily newspaper, magazine, computer, internet access, and at least fifty books. Family structure is measured by the presence of both biological parents in the household and the adolescent's number of siblings.

A second set of controls focuses on adolescents' general academic attitudes and behaviors, including a measure of the adolescent's educational attainment expectations and scales of the degree to which the adolescent reports holding positive attitudes toward learning and engaging in negative behaviors (the latter also includes reports from $10^{\text {th }}$ grade reading and math teachers). Multi-group analyses focused on these attitudinal/behavioral scales provide more insight on the internal validity of the study. (More details on the results discussed here are available in Online Tables 2-4.) Factor loadings and uniqueness indicate some differences in the meaning of 'positive attitudes 
toward math coursework as a 10th grader' for designated and undesignated adolescents. Importantly, all factor loadings are parallel between designated and undesignated adolescents. Although there are small differences by LD status, each scale's Cronbach's alpha was higher than 0.70 for both designated and undesignated adolescents. The scales' standard deviations were similar although typically slightly larger for designated than undesignated adolescents.

Continuing the multi-group analyses, logistic regression models show each scale relates to math course attainment in the same direction for designated and undesignated adolescents, although coefficients are typically slightly smaller for designated adolescents. Standard errors are generally larger for designated than undesignated adolescents, particularly for the relationship between negative social behaviors and math course attainment. Focusing on the relatively larger differences in model fit, negative academic behaviors per $10^{\text {th }}$ grade math teacher explained less of the variation in designated than undesignated adolescents' math course attainment. The Hosmer-Lemeshow test also suggests this scale produces a less well-fit model for designated than undesignated adolescents (lower chi-square). Similarly, Pearson's chi-square suggests negative social behaviors produce a more poorly fit model for designated than undesignated adolescents.

A third set of controls focuses on each adolescent's performance in and attitudes toward math. Levels of $9^{\text {th }}$ and $10^{\text {th }}$ grade math, which include courses adolescents attempted but did not pass, are each measured with four categories: No math, Lower than Algebra I, Algebra I, and Geometry or higher. Performance in math is captured with grade point averages in math, the numbers of $9^{\text {th }}$ and $10^{\text {th }}$ grade math semesters failed, and score on the standardized $10^{\text {th }}$ grade math test. Scales describe the degree to which adolescents 
hold positive attitudes toward math coursework per their own reports, and engage in negative behaviors per the reports of their $10^{\text {th }}$ grade math teachers. A final control measures whether each adolescent dropped out of school after the $10^{\text {th }}$ grade.

\subsection{Analytic plan}

Analyses for this study were conducted using Stata. Descriptive statistics showed sociodemographic, academic, attitudinal, and behavioral differences between designated and undesignated adolescents. Estimates from ordered logistic regression models demonstrated the total effect of an LD designation on adolescents' math course attainment by the end of high school, with an initial model showing baseline differences and a final model including all controls. To explore the potential production of stigma, logistic regression models estimated disparities by LD status in 1) $10^{\text {th }}$ grade math course progression (separation), 2) 10 ${ }^{\text {th }}$ grade math teachers' attributions for adolescents' performance levels (labeling), and 3) $10^{\text {th }}$ grade math teachers' educational attainment expectations for adolescents (stereotyping). Tenth grade math course progression was predicted with controls for adolescents' social and academic backgrounds, and level of and performance in their $9^{\text {th }}$ grade math coursework. Models predicting teachers' attributions and expectations additionally included controls for adolescents' level of and performance in their $10^{\text {th }}$ grade math coursework, attitudes and behaviors in their math coursework, math test score, and general academic attitudes and behaviors.

Because this data is clustered, the models predicting $10^{\text {th }}$ grade math course progression, and teachers' attributions and expectations were population-averaged multilevel models. Because multilevel modeling was not yet available for ordered logistic regression modeling, standard errors were clustered in the models predicting math course 
attainment by the end of high school. To facilitate interpretation and address issues of scaling unique to logistic regression models, all results from the models were presented using predicted probabilities_-predicted probabilities can be compared across models whereas coefficients from logit models should not be (Mood, 2010). Predicted probabilities were average probabilities, as the alternative, setting all controls to their means, typically represents cases that realistically do not exist (Williams, 2011). Full models are available online (Online Tables 5 and 6).

Finally, a decomposition method developed by Kohler, Karlson, and Holm (2011) was used to determine whether labeling, stereotyping, and separation culminate in poorer outcomes. By decomposing the negative effect of an LD designation on math course attainment into direct and indirect effects, this method established direct links between the LD designation, measured correlates of the LD designation, and outcomes shown to be impacted by the LD designation. The indirect effect represents the percent of the effect attributable to disparities by LD status in $10^{\text {th }}$ grade math course progression, and math teachers' attributions and expectations. This method also determined the contribution of each mediator to the total effect, net of controls and other mediators. Previous studies have used standard regression techniques to show mediation, but comparing coefficients across logistic models is increasingly perceived as problematic because of issues of scaling (Mood, 2010). In addition to addressing these issues of scaling (Kohler, Karlson and Holm 2011), this decomposition method more tangibly communicates effect sizes.

\section{Results}

3.1 Disparities by learning disability status 
In addition to providing descriptive statistics, Table 1 shows differences in the social and academic backgrounds, and attitudes and behaviors, of adolescents with and without an LD designation. Adolescents with an LD designation are more socially disadvantaged and exhibit more negative academic attitudes and behaviors than adolescents without a disability designation. Adolescents with an LD designation scored lower on the $10^{\text {th }}$ grade math test, achieved poorer grades, failed more semesters of math, and were more likely to drop out of school than undesignated adolescents. These statistics highlight why it is important to use multivariate techniques that control for these differences.

\section{Table 1 About Here}

Figure 1 shows predicted probabilities from regression models (full models available online) to examine the extent to which there are disparities in high school math course attainment by LD status, both at the baseline and after accounting for differences by LD status in background, performance, attitudes, and behaviors. Predicted probabilities, expressed as percentages, are more intuitive than log odds; percentages are also preferable to odds ratios because they are bounded (percentages range from 0 to 100 whereas odds ratios have no upper limit). In contrast to $74 \%$ (i.e., $51 \%+23 \%$ ) of adolescents without a disability designation, only $25 \%$ of adolescents with an LD designation are predicted to attempt at least Algebra II by the end of high school (Model A1). Most striking, 34\% of adolescents designated with an LD are predicted to finish high school having never attempted Algebra I, the course most adolescents take in the $9^{\text {th }}$ grade (Model A1). In the model with all controls, $72 \%$ of undesignated adolescents and $60 \%$ of designated adolescents are predicted to attempt at least Algebra II by the end of high school (Model A2). The reduced gap suggests designated adolescents' poorer outcomes are partially 
attributable to their poorer academic, attitudinal, and behavioral profiles, but their math course attainment net of these differences still remains significantly lower than that of undesignated adolescents.

Figure 1 About Here

\subsection{Production of stigma: Labeling, stereotyping, and separation}

Figure 2 shows predicted probabilities from baseline regression models and models with controls (full models available online) to examine whether designated adolescents appear to experience labeling, stereotyping, and separation during early high school. More specifically, the estimates show disparities in the predicted probabilities that designated and undesignated adolescents' math teachers attribute their performance to disability (Models A1 and A2) and expect them to complete at least a bachelor's degree (Models B1 and B2), and whether their level of $10^{\text {th }}$ grade math is higher than their level of $9^{\text {th }}$ grade math (Models $\mathrm{C} 1$ and $\mathrm{C} 2$ ). In one example, at the baseline, the math teachers of $8 \%$ of adolescents without a disability designation and $67 \%$ of adolescents designated with disability are predicted to attribute the adolescent's performance to disability (Model A1). Net of differences in math course level and performance, attitudes, and behaviors, math teachers remain significantly more likely to at least partially attribute the performance of designated adolescents to a disability than they are that of undesignated adolescents (Model A2). By seemingly interpreting the LD designation as objective and important information, teachers may enable the transformation of the LD designation into a label.

Figure 2 About Here

Similarly, math teachers have significantly lower educational attainment expectations for designated adolescents than they do for undesignated adolescents even 
net of differences in achievement and behaviors (Figure 2, Model B2), suggesting the school LD designation may be linked to negative stereotypes. Net of differences in $9^{\text {th }}$ grade math course level and performance, designated adolescents are significantly less likely to experience progression in their $10^{\text {th }}$ grade math course placement (Figure 2, Model C2). These results suggest adolescents with an LD designation may experience separation, an element of stigma in which access to important life domains is denied.

\subsection{Lower math course attainment as a result of stigma related to the LD designation}

Figure 3 uses estimates from a decomposition analysis to demonstrate the degree to which labeling, stereotyping, and separation, as measured by disparities in attributions, expectations, and course placements, appear to actually contribute to designated adolescents' lower levels of math course attainment by the end of high school. The bar on the left shows that, net of controls, $51 \%$ of the total effect of the LD designation on math course attainment is an indirect effect, or is attributable to the mediators measured in this study (disparities in early high school math course progression, and in math teachers' attributions and expectations). The direct effect of $49 \%$ suggests the LD designation is also associated with math course attainment via unmeasured factors (perhaps unmeasured school processes related to LD designations)—see Blakely (2002) for more on direct effects. Importantly, in addition to adjusting for the influence of differences across controls, this decomposition method accounts for the influence of other mediators $\left(10^{\text {th }}\right.$ grade math course level and teachers' attributions, for instance) when estimating the contribution of a single mediator (teachers' expectations, for instance).

Figure 3 About Here 
The bar on the right in Figure 3 shows that, net of all controls and the other mediators, $36 \%$ of the total effect of the LD designation is mediated through the placement of designated adolescents into a level of $10^{\text {th }}$ grade math not higher than the level of their $9^{\text {th }}$ grade math course. Net of all controls and other mediators, $8 \%$ of the total negative effect of the LD designation on math course attainment is mediated by math teachers' at least partial attributions of designated adolescents' performance to disability. Finally, 7\% of the total negative effect of the LD designation on math course attainment is mediated by math teachers' lower educational attainment expectations for designated adolescents, net of all controls and other mediators. By establishing direct links between the LD designation, inequitable correlates of the designation, and ultimate math course attainment, these results suggest designated adolescents experience poorer outcomes in part because of labeling, stereotyping, and separation-that is, because of stigma.

\section{Discussion}

\subsection{Summary of presented findings}

This study finds tangible evidence that stigma may be a factor in the poorer outcomes of youth designated with an LD. Building on evidence that LD designation processes are inconsistent and subjective (Fletcher et al., 2005), this study compared designated and undesignated adolescents with similar potential for progression through math coursework, as evidenced by their academic records, attitudes, and behaviors as of early high school. This study's findings broadly support the ideas of a modified labeling theory, in that designated youths' poorer outcomes appear to be at least partially attributable to stigma related to labeling. This study's findings also suggest potential 
targets for policy reform, particularly as labeling low achievement as an LD is in some part socially constructed and may reproduce disadvantage.

At some point in their academic careers, some low achievers are designated as learning disabled, with many carrying this designation through high school and even college (Blackorby et al., 2010). In Link and Phelan's framework, labeling describes the perception of a difference as objective and important. If teachers do not attribute student performance to disability because they are unaware of the adolescent's school LD designation or discredit it, the school designation is not 'important' enough to produce stigma. This study, though, found teachers were more likely to at least partially attribute designated adolescents' performance levels to disability than they were that of similarly achieving undesignated peers. This suggests the LD designation may function as a label.

Alternatively, teachers may be aware that adolescents' potential as measured in this study—course level, course grades, test scores—required greater levels of effort from designated than undesignated adolescents, or a greater degree of educational intervention. If so, or if this effort is not sustained, then comparing adolescents with similar test scores may obscure differences in course-taking potential between adolescents with an LD designation and their peers. Put simply, with the possibility of unmeasured factors, teachers' attributions and expectations may be more accurate or realistic than they appear to be based on the achievement evidence in this study (Jussim \& Harber, 2005). With this study focused on differences by LD status, net of correlated differences in achievement, attitudes, and behaviors, teacher attributions or expectations based on unmeasured more subjective indicators of potential (e.g., mannerisms, expected support) may still indicate stigma, just not stigma sourced in the LD designation. Even the possibility that LD 
designations produce stigma merits further study, especially given dominant perspectives of LDs as stable, internal, and uncontrollable conditions (Clark, 1997).

In all, this study's findings related to teachers support previous findings on teacher expectancy effects (Jussim \& Eccles, 1992; Kaiser et al., 2013). By attributing academic performance to disability, both students and teachers are relieved to some extent of the burden of responsibility and control for performance. As a point of contrast, a student whose low performance is attributed to low effort can presumably still benefit from intensified or altered inputs from teachers. In addition to the negative implications for individual youths' academic careers (Kunter et al., 2008), this process of 'masking and misrecognizing' the social causes for low achievement threatens our clear understanding of both the development of learning ability and the mechanisms of social reproduction (Carrier, 1983); with LD designations, low achievement becomes a product of individual deficiency rather than social inequities in homes and schools. Labeling low achievement as an LD may essentially pathologize poverty (Carrier, 1983).

Status and stigma both describe hierarchical categories. Phelan, Lucas, Ridgeway, and Taylor (2014) point out, though, that lower status categories (e.g., female) are often still considered 'normal' whereas stigmatized categories, by definition, are not. All low achievers, regardless of whether they are designated with disability, experience disparities in educational attainment. Yet, this study finds teachers hold significantly lower educational attainment expectations for designated adolescents than they do for similarly achieving and behaving undesignated adolescents. This suggests the LD designation is linked with negative stereotypes. Similarly, teachers described designated children in vignettes as having less control over their performance and being more likely to continue 
having difficulties than undesignated children with identical patterns of performance and behaviors (Woolfson, Grant, \& Campbell, 2007). It is possible the degree to which teachers' educational attainment expectations contribute to disparities in academic outcomes would only be magnified if this study had access to data on more than one of adolescents' teachers.

Early high school math course placements contributed the most to designated youths' lower math course attainment in part because of the hierarchical nature of math course-taking in the US. Previous studies on teachers as course gatekeepers (Eder, 1981; Riehl, 2001), particularly for students in special education (Mehan, Hertweck, \& Meihls, 1986), though, support the idea that inequitable course placements may also reflect stigma related to LD designations. US federal guidelines require the review of the progression of youth in special education on an annual basis by a panel of administrators, teachers, and parents (U.S. Department of Education, 2007). Despite functional intentions, meetings like these may facilitate the dissemination of stereotypes related to LD designations. This study's findings may even be conservative estimates if designated adolescents experienced similar processes of course stratification before the tenth grade.

\subsection{Limitations of the study}

As discussed in the preceding paragraphs, a main limitation of this study involves the possibility that the disparities designated adolescents seem to experience in their $10^{\text {th }}$ grade math course placements, their teachers' attributions and expectations, and their math course attainment by the end of high school are the result of unmeasured correlates of LD designations rather than the designations themselves. It is difficult to say with certainty whether designated students' lower levels of $10^{\text {th }}$ grade math reflect the influence 
of their own self-doubt, lowered expectations of their teachers and parents, or institutionalized processes within schools. Moreover, multi-group analyses showed some differences by LD status in the meanings of the attitudinal/behavioral constructs used as controls in this study (discussed in more detail in Method section). Omitted variable bias may influence estimates for designated adolescents to a slightly larger degree than those for undesignated adolescents. While this bias may represent unmeasured cognitive differences, it could also represent systematic differences in social experiences related to stigma and stratification. Nonetheless, these differences suggest findings should be interpreted with some caution.

The decomposition analyses demonstrate whether the negative effect of the LD designation on math course attainment is mechanized through measured qualities, namely adolescents' $10^{\text {th }}$ grade math course placement and teachers' attributions and expectations (indirect effects), as well as the degree to which expectations are attributable to a 'direct effect' of the LD designation (i.e., unmeasured factors common to designated adolescents). So although designated adolescents' math course progression may be a function of their own choices or of differences in encouragement from their parents rather their teachers, these unmeasured factors are likely encapsulated by the direct effect of the LD designation rather than being implicated in teachers' attributions or expectations. Nonetheless, the potential contributions of unmeasured factors should not be discounted.

In another limitation, about a quarter of sampled students were excluded from analyses because their schools did not report the disability status of any sampled students. These findings cannot be generalized to the national population of adolescents in the US because of average differences between excluded adolescents and adolescents in the 
analytic sample. In additional sensitivity analyses, the models predicting adolescents' math course attainment by the end of high school were estimated with four different samples of students (Online Table 5). The first estimation uses this study's main analytic sample, which includes adolescents whose schools provided disability reports for all or some sampled students. Adolescents whose schools reported the disability status of all sampled students are used for the second estimation; some sampled students for the third; and all, some, or no sampled students for the fourth. Although effect size varied slightly, results are substantively consistent across these four estimations, with adolescents designated with an LD progressing significantly less far in their math coursework than adolescents without a disability designation, even controlling for prior achievement and other factors. These sensitivity analyses provide more confidence in the results presented here. Even after excluding cases, this study uses a much larger and more diverse analytic sample than most previous studies on LDs.

\subsection{Conclusion and implications}

Despite alternative interpretations, even the possibility that LD designations stymy adolescents' academic progression through inequitable course placements, and their teachers' more negative attributions and expectations, suggests further investigation and possible policy reform is warranted. Rather than intentionally or consciously disadvantaging designated adolescents, teachers' attributions and expectations may be altered as a result of their misunderstanding or misrecognition of the subjectivity or meaning of LD designations (Thornicroft, Rose, Kassam, \& Sartorius, 2007). Future research might also explore variation across teachers in the extent to which their expectations are informed by disability designations. Previous studies find teachers can 
positively alter the experiences of youth (Archambault, Pagani, \& Fitzpatrick, 2013; Assor, Kaplan, Kanat-Maymon, \& Roth, 2005), including those designated with disabilities (Kiuru et al., 2012). An increased understanding of LDs and the diagnostic process may promote attributions and expectations for designated adolescents more consistent with their achievement levels (Förster \& Souvignier, 2014; Granström, 1995). Policy efforts might also focus on increasing general public knowledge on LDs and improving special education programming by incorporating checks to ensure equitable progression. Finally, these findings reinforce the notion that although labels have an essential function in our society, their power to shape perceptions and experiences must be a constant consideration. 


\section{References}

Adelman, C. (2006). The toolbox revisited-Paths to degree completion from high school through college. Washington, DC: U.S. Department of Education.

Allday, R. A., Duhon, G. J., Blackburn-Ellis, S., \& Dycke, J. L. V. (2011). The biasing effects of labels on direct observation by preservice teachers. Teacher Education Quarterly, 34, 52-58.

American Psychiatric Association. (2000). Diagnostic and statistical manual of mental disorders, fourth edition. Washington, DC: American Psychiatric Association.

Archambault, I., Pagani, L. S., \& Fitzpatrick, C. (2013). Transactional association between classroom engagement and relations with teachers from first through fourth grade.

Learning and Instruction, 23, 1-9.

Assor, A., Kaplan, H., Kanat-Maymon, Y., \& Roth, G. (2005). Directly controlling teacher behaviors as predictors of poor motivation and engagement in girls and boys: The role of anger and anxiety. Learning and Instruction, 15, 397-413.

Becker, D. (2013). The impact of teachers' expectations on students' educational opportunities in the life course: An empirical test of a subjective expected utility explanation. Rationality and Society, 25, 422-469.

Benner, A. D., \& Mistry, R. S. (2007). Congruence of mother and teacher educational expectations and low-income youth's academic competence. Journal of Educational Psychology, 99, 140-153.

Blackorby, J., Schiller, E., Mallik, S., Hebbeler, K., Huang, T., Javitz, H., Marder, C., Nagle, K., Shaver, D., Wagner, M., \& Williamson, C. (2010). Patterns in the identification of and outcomes for children and youth with disabilities (NCEE 2010-4005). Washington DC: 
National Center for Education Evaluation and Regional Assistance, Institute of Education Sciences, U.S. Department of Education.

Blakely, T. (2002). Commentary: Estimating direct and indirect effects-fallible in theory, but in the real world? International Journal of Epidemiology, 31, 166-167.

Carrier, J. G. (1983). Masking the social in educational knowledge: The case of learning disability theory. The American Journal of Sociology, 88, 948-974.

Clark, M. D. (1997). Teacher response to learning disability: A test of attributional principles. Journal of Learning Disabilities, 30, 69-79.

Coughlin, D. (1997). The person with a learning disability as a minority group member. Journal of Learning Disabilities, 30, 572-575.

Devine, A., Soltész, F., Nobes, A., Goswami, U., \& Szücs, D. (2013). Gender differences in developmental dyscalculia depend on diagnostic criteria. Learning and Instruction, 27, $31-39$.

Dudley-Marling, C. (2004). The social construction of learning disabilities. Journal of Learning Disabilities, 37, 482-489.

Eccles, J. S., \& Wigfield, A. (1985). Teacher expectancies and student motivation. In J. B. Dusek (Ed.), Teacher Expectancies (pp. 185-226). Hillsdale, NJ: Erlbaum.

Eder, D. (1981). Ability grouping as a self-fulfilling prophecy: A micro-analysis of teacherstudent interaction. Sociology of Education, 54, 151-162.

Eyal, G. (2013). For a sociology of expertise: The social origins of the autism epidemic. American Journal of Sociology, 118, 863-907. 
Fletcher, J. M., Denton, C., \& Francis, D. J. (2005). Validity of alternative approaches for the identification of learning disabilities: Operationalizing unexpected underachievement. Journal of Learning Disabilities, 38, 545-552.

Förster, N., \& Souvignier, E. (2014). Learning progress assessment and goal setting: Effects on reading achievement, reading motivation and reading self-concept. Learning and Instruction, 32, 91-100.

Gamoran, A., \& Mare, R. D. (1989). Secondary school tracking and education inequality: Compensation, reinforcement, or neutrality? American Journal of Sociology, 94, 11461183.

Gamoran, A., Porter, A. C., Smithson, J., \& White, P. A. (1997). Upgrading high school mathematics instruction: Improving learning opportunities for low-achieving, lowincome youth. Educational Evaluation and Policy Analysis, 19, 325-338.

Gill, S., \& Reynolds, A. J. (1999). Educational expectations and school achievement of urban african american children. Journal of School Psychology, 37, 403-424.

Good, C., Aronson, J., \& Inzlicht, M. (2003). Improving adolescents' standardized test performance: An intervention to reduce the effects of stereotype threat. Applied Developmental Psychology, 24, 645-662.

Good, T. L. (1981). Teacher expectations and student perceptions: A decade of research. Educational Leadership, 38, 415-422.

Granström, K. (1995). Accounts and explanations in group decisions concerning students with learning and social disabilities. Learning and Instruction, 5, 125-141.

Hibel, J., Farkas, G., \& Morgan, P. L. (2010). Who is placed into special education? Sociology of Education, 83, 312-332. 
Hudson, L., \& O'Rear, I. (2015). Ninth-graders' mathematics coursetaking, motivations, and educational plans. Washington DC: National Center for Education Statistics, U.S. Department of Education.

Jingree, T., \& Finlay, W. M. L. (2012). 'It's got so politicaly correct now': Parents' talk about empowering individuals with learning disabilities. Sociology of Health \& Illness, 34, 412-428.

Jussim, L. (1989). Teacher expectations: Self-fulfillling prophecies, perceptual biases, and accuracy. Journal of Personality and Social Psychology, 57, 469-480.

Jussim, L., \& Eccles, J. S. (1992). Teacher expectations II: Construction and reflection of student achievement. Journal of Personality and Social Psychology, 63, 947-961.

Jussim, L., \& Harber, K. D. (2005). Teacher expectations and self-fulfilling prophecies: Knowns and unknowns, resolved and unresolved controversies. Personality and Social Psychology Review, 9, 131-155.

Jussim, L., Smith, A., Madon, S., \& Palumbo, P. (1998). Teacher expectations. In J. Brophy (Ed.), Advances in Research on Teaching (Vol. 7, pp. 1-48). Greenwich, CT: JAI.

Kaiser, J., Retelsdorf, J., Südkamp, A., \& Möller, J. (2013). Achievement and engagement: How student characteristics influence teacher judgments. Learning and Instruction, 28, 73-84.

King, M. D., \& Bearman, P. S. (2011). Socioeconomic status and the increased prevalence of autism in California. American Sociological Review, 76, 320-346.

King, M. D., Jennings, J., \& Fletcher, J. (2014). Medical adaptation to academic pressure: Schooling, stimulant use, and socioeconomic status. American Sociological Review, 79, 1039-1066. 
Kiuru, N., Poikkeus, A.-M., Lerkkanen, M.-K., Pakarinen, E., Siekkinen, M., Ahonen, T., \& Nurmi, J.-E. (2012). Teacher-perceived supportive classroom climate protects against detrimental impact of reading disability risk on peer rejection. Learning and Instruction, $22,331-339$

Kohler, U., Karlson, K. B., \& Holm, A. (2011). Comparing coefficients of nested nonlinear probability models. The Stata Journal, 11, 420-438.

Krajewsi, K., \& Schneider, W. (2009). Exploring the impact of phonological awareness, visualspatial working memory, and preschool quantity-number competencies on mathematics achievement in elementary school: Findings from a 3-year longitudinal study. Journal of Experimental Child Psychology, 103, 516-531.

Kunter, M., Tsai, Y.-M., Klusmann, U., Brunner, M., Krauss, S., \& Baumert, J. (2008).

Students' and mathematics teachers' perceptions of teacher enthusiasm and instruction. Learning and Instruction, 18, 468-482.

Lackaye, T. D., \& Margalit, M. (2006). Comparisons of achievement, effort, and selfperceptions among students with learning disabilities and their peers from different achievement groups. Journal of Learning Disabilities, 39, 432-446.

Lester, G., \& Kelman, M. (1997). State disparities in the diagnosis and placement of pupils with a learning disability. Journal of Learning Disabilities, 30, 599-606.

Link, B. G., Cullen, F. T., Struening, E., Shrout, P. E., \& Dohrenwend, B. P. (1989). A modified labeling theory approach to mental disorders: An empirical assessment. American Sociological Review, 54, 400-423.

Link, B. G., \& Phelan, J. C. (2001). Conceptualizing stigma. Annual Review of Sociology, 27, $363-385$ 
Madon, S., Jussim, L., \& Eccles, J. (1997). In search of the powerful self-fulfilling prophecy. Journal of Personality and Social Psychology, 72, 791-809.

McFarland, D. A. (2006). Curricular flows: Trajectories, turning points, and assignment criteria in high school math careers. Sociology of Education, 79, 177-205.

McLeod, J. D., \& Kaiser, K. (2004). Childhood emotional and behavioral problems and educational attainment. American Sociological Review, 69, 636-658.

Mehan, H., Hertweck, A., \& Meihls, J. L. (1986). Handicapping the handicapped: Decision making in students' educational careers. Stanford, CA: Stanford University Press.

Mistry, R. S., White, E. S., Benner, A. D., \& Huynh, V. W. (2009). A longitudinal study of the simultaneous influence of mothers' and teachers' educational expectations on lowincome youth's academic achievement. Journal of Youth and Adolescence, 38, 826-838.

Mood, C. (2010). Logistic regression: Why we cannot do what we think we can do and what we can do about it. European Sociological Review, 26, 67-82.

Morgan, P. L., Frisco, M., Farkas, G., \& Hibel, J. (2010). A propensity score matching analysis of the effects of special education services. The Journal of Special Education, 43, 236254.

Morgan, P. L., Staff, J., Hillemeier, M. M., Farkas, G., \& Maczuga, S. (2013). Racial and ethnic disparities in ADHD diagnosis from kindergarten to eighth grade. Pediatrics, 132, 85-93.

National Center for Education Statistics. (2010). AERA professional development course, PDC09 - ELS: 2002 survey design and analysis. Paper presented at the American Educational Research Association, Denver, CO. 
Noguera, P. (2003). City schools and the american dream: Reclaiming the promise of public education. New York, NY: Teachers College Press.

Oakes, J. (2009 [1985]). Keeping track: How schools structure inequality. In C. Kridel (Ed.), Classic Edition Sources: Education, Fourth Edition (pp. 103-109). New York, NY: McGraw-Hill.

Office of Special Education Programs. (n.d.). History - Twenty-five years of progress in educating children with disabilities through IDEA. Washington, DC: Office of Special Education Programs, Office of Special Education and Rehabilitative Services, United States Department of Education.

Ohan, J. L., Visser, T. A. W., Strain, M. C., \& Allen, L. (2011). Teachers' and education students' perceptions of and reactions to children with and without the diagnostic label "ADHD". Journal of School Psychology, 49, 81-105.

Ong-Dean, C. (2009). Distinguishing disability: Parents, privilege, and special education. Chicago, IL: The University of Chicago Press.

Phelan, J. C. (2005). Geneticization of deviant behavior and consequences for stigma: The case of mental illness. Journal of Health and Social Behavior, 46, 307-322.

Phelan, J. C., Lucas, J. W., Ridgeway, C. L., \& Taylor, C. J. (2014). Stigma, status, and population health. Social Science \& Medicine, 103.

Riehl, C. (2001). Bridges to the future: The contributions of qualitative research to the sociology of education. Sociology of Education, 74, 115-134.

Rubie-Davies, C. M. (2006). Teacher expectations and student self-perceptions: Exploring relationships. Psychology in the Schools, 43, 537-552. 
Samson, J. F., \& Lesaux, N. K. (2009). Language-minority learners in special education: rates and predictors of identification for services. Journal of Learning Disabilities, 42, 148162.

Schneider, B., Swanson, C. B., \& Riegle-Crumb, C. (1998). Opportunities for learning: course sequences and positional advantages. Social Psychology of Education, 2, 25-53.

Sciarra, D. T., \& Ambrosino, K. E. (2011). Post-secondary expectations and educational attainment. Professional School Counseling, 14, 231-241.

Shifrer, D. (2013). Stigma of a label: Educational expectations for high school students labeled with a learning disability. Journal of Health and Social Behavior, 54, 462-480.

Shifrer, D., Callahan, R., \& Muller, C. (2013). Equity or marginalization? The high school course-taking of students labeled with a learning disability. American Educational Research Journal, 50, 656-682.

Shifrer, D., Muller, C., \& Callahan, R. (2011). Disproportionality and learning disabilities: Parsing apart race, socioeconomic status, and language. Journal of Learning Disabilities, $44,246-257$.

Singer, J. D., Palfrey, J. S., Butler, J. A., \& Walker, D. K. (1989). Variation in special education classification across school districts: How does where you live affect what you are labeled? American Educational Research Journal, 26, 261-281.

Sorhagen, N. S. (2013). Early teacher expectations disproportionately affect poor children's high school performance. Journal of Educational Psychology, 105, 465-477.

Spellings, M., Knudsen, W. W., \& Guard, P. J. (2007). 27th annual (2005) report to Congress on the implementation of the Individuals with Disabilities Education Act, Vol. 1. 
Washington, DC: Office of Special Education Programs, Office of Special Education and Rehabilitative Services, U.S. Department of Education.

Strand, S., \& Lindsay, G. (2009). Ethnic disproportionality in special education: Evidence from an English population study. Journal of Special Education, 43, 174-190.

Thornicroft, G., Rose, D., Kassam, A., \& Sartorius, N. (2007). Stigma: Ignorance, prejudice or discrimination? British Journal of Psychiatry, 190, 192-193.

U.S. Department of Education. (2007). A guide to the Individualized Education Program. My Child's Special Needs. Retrieved June 2013, 2013. From http://www2.ed.gov/parents/needs/speced/iepguide/index.html\#review.

Vellutino, F. R., Fletcher, J. M., Snowling, M. J., \& Scanlon, D. M. (2004). Specific reading disability (dyslexia): What have we learned in the past four decades? Journal of Child Psychology and Psychiatry, 45, 2-40.

Wagner, M., Newman, L., Cameto, R., \& Levine, P. (2006). The academic achievement and functional performance of youth with disabilities: A report from the National Longitudinal Transition Study-2 (NLTS2). (NCSER 2006-3000). Menlo Park, CA: SRI International.

Williams, R. (2011). Using the margins command to estimate and interpret adjusted predictions and marginal effects. Paper presented at the Stata Conference, Chicago, IL.

Woolfson, L., Grant, E., \& Campbell, L. (2007). A comparison of special, general and support teachers' controllability and stability attributions for children's difficulties in learning. Educational Psychology, 27, 295-306. 
Wu, C.-L., \& Bai, H. (2015). From early aspirations to actual attainment: The effects of economic status and educational expectations on university pursuit. Higher Education, $69,331-344$. 
Table 1: Descriptive Statistics by Learning Disability Status

\begin{tabular}{|c|c|c|c|c|c|}
\hline \multirow{2}{*}{ Social \& Academic Background } & \multicolumn{2}{|c|}{$\begin{array}{l}\text { No disability } \\
\text { designation }\end{array}$} & \multicolumn{2}{|c|}{$\begin{array}{l}\text { Learning } \\
\text { disability } \\
\text { designation }\end{array}$} & \multirow[b]{3}{*}{$* * *$} \\
\hline & & & & & \\
\hline Male & 0.49 & & 0.66 & & \\
\hline Race: & & & & & $* * *$ \\
\hline White & 0.62 & & 0.57 & & \\
\hline Black & 0.13 & & 0.16 & & \\
\hline Hispanic & 0.16 & & 0.17 & & \\
\hline Asian & 0.03 & & 0.02 & & \\
\hline Other race & 0.05 & & 0.09 & & \\
\hline Socioeconomic status & 0.05 & $(0.73)$ & -0.27 & $(0.65)$ & $* * *$ \\
\hline Cognitive resources in household & 3.90 & $(1.23)$ & 3.39 & $(1.39)$ & $* * *$ \\
\hline Both biological parents in household & 0.59 & & 0.47 & & $* * *$ \\
\hline Number of siblings & 2.31 & $(1.51)$ & 2.69 & $(1.67)$ & $* * *$ \\
\hline Parent's educational expectations for 10th grader & 4.98 & $(1.37)$ & 3.59 & $(1.49)$ & $* * *$ \\
\hline Ever in remedial English & 0.08 & & 0.19 & & $* * *$ \\
\hline Ever in remedial math & 0.09 & & 0.18 & & $* * *$ \\
\hline Ever retained a grade & 0.11 & & 0.38 & & $* * *$ \\
\hline Age at 10 th grade survey & 15.85 & $(0.62)$ & 16.16 & $(0.73)$ & $* * *$ \\
\hline \multicolumn{6}{|l|}{ Performance in and Attitudes Toward Math } \\
\hline Positive attitudes toward math as 10 th grader & 15.59 & $(5.40)$ & 14.58 & $(4.17)$ & $* * *$ \\
\hline $\begin{array}{l}\text { Negative academic behaviors per 10th grade } \\
\text { math teacher }\end{array}$ & 3.26 & $(3.02)$ & 4.55 & $(3.20)$ & $* * *$ \\
\hline Level of 9th grade math & 1.94 & $(0.77)$ & 1.28 & $(0.66)$ & $* * *$ \\
\hline GPA in 9th grade math courses & 2.47 & $(1.13)$ & 2.02 & $(1.09)$ & $* * *$ \\
\hline Semesters of 9 th grade math cours ework failed & 0.17 & (1.39) & 0.25 & (1.69) & $* * *$ \\
\hline GPA in 10 th grade math courses & 2.32 & $(1.17)$ & 1.17 & $(1.06)$ & $* * *$ \\
\hline Semesters of 10th grade math coursework failed & 0.21 & $(0.59)$ & 0.29 & $(0.66)$ & $* * *$ \\
\hline Score on 10 th grade math test & 51.52 & (9.39) & 39.71 & $(8.38)$ & $* * *$ \\
\hline \multicolumn{6}{|l|}{ General Academic Attitudes and Behaviors } \\
\hline Negative behaviors per 10th grader & 6.59 & $(4.32)$ & 9.01 & $(5.41)$ & $* * *$ \\
\hline Negative social behaviors per 10th grade teachers & 5.28 & $(3.65)$ & 7.44 & $(4.54)$ & $* * *$ \\
\hline 10th grader's positive attitudes toward learning & 21.27 & (7.07) & 17.58 & $(6.73)$ & $* * *$ \\
\hline 10th grader's educational expectations & 5.21 & $(1.39)$ & 3.94 & $(1.69)$ & $* * *$ \\
\hline Dropped out after 10 th grade & 0.04 & & 0.10 & & $* * *$ \\
\hline Students (n) & & 170 & 62 & 20 & \\
\hline
\end{tabular}

Note: Standard deviations provided within parentheses next to means. $+p<0.10, * p<0.05, * * p<0.01, * * * p<0.001$. 
Figure 1. Poorer outcomes - Predicted probabilities by learning disability status of adolescents' math course attainment

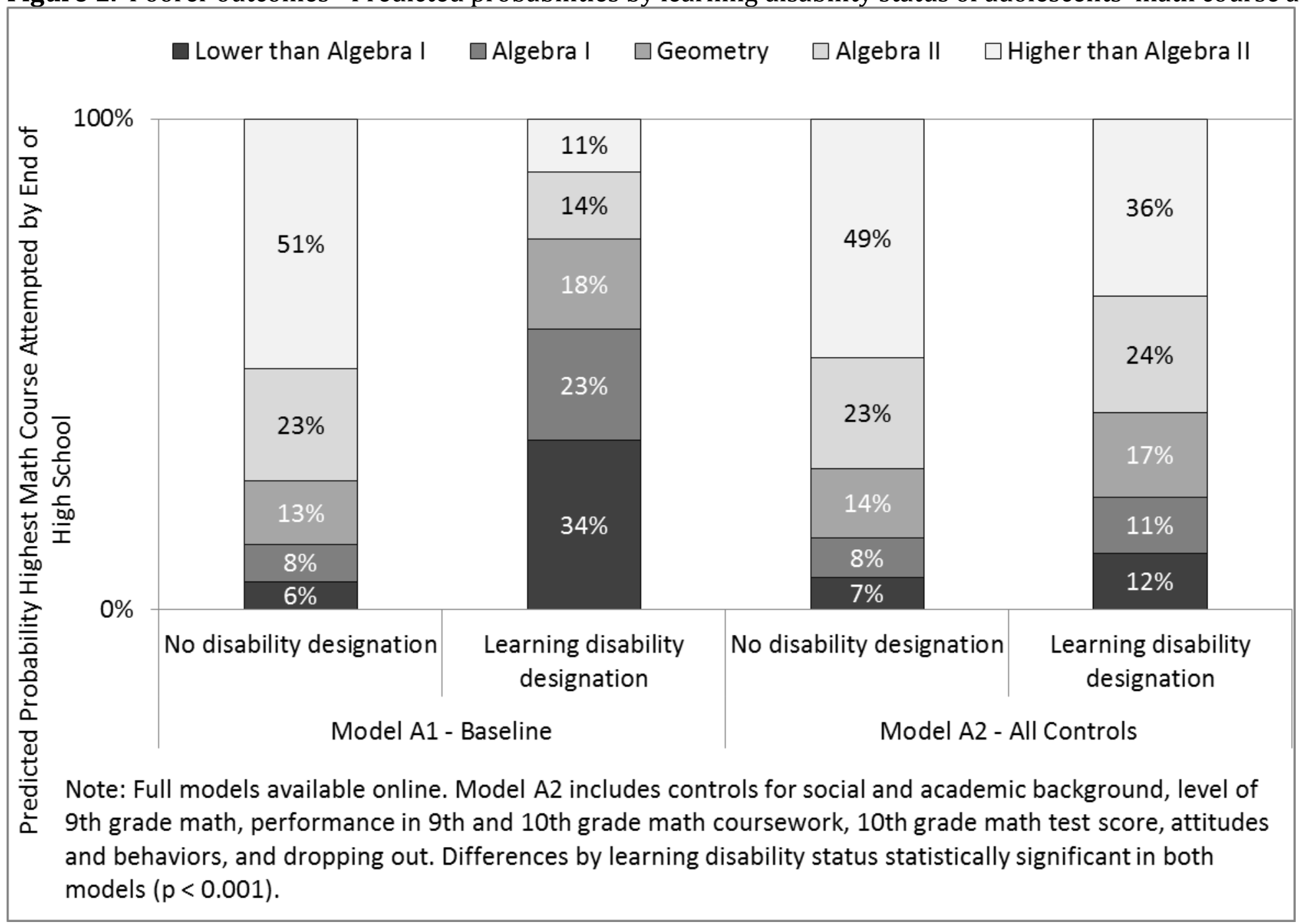


Figure 2. Labeling, stereotyping, and separation - Predicted probabilities by learning disability status of math teachers' attributions and expectations, and 10th grade math course progression

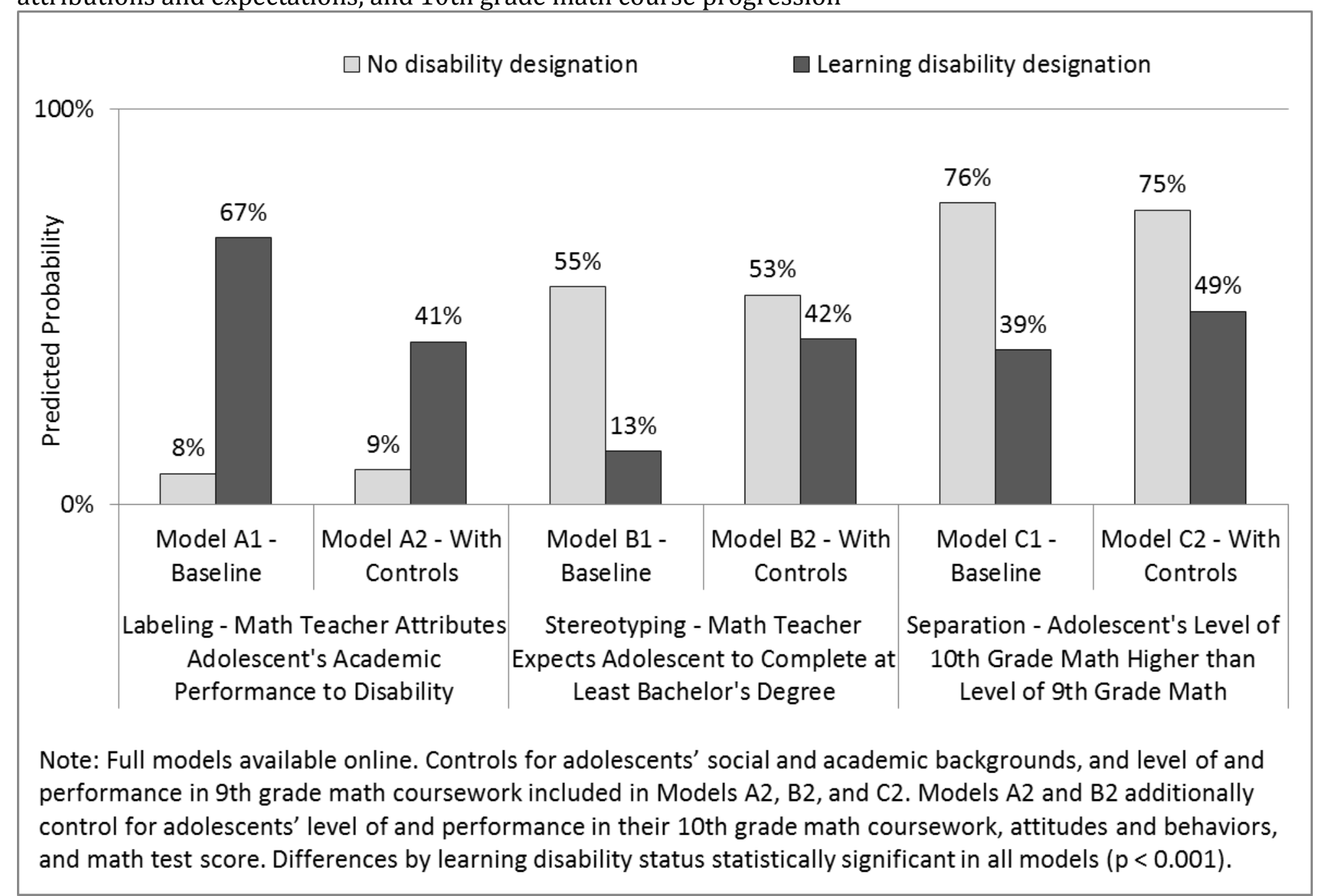


Figure 3. Status loss and discrimination - Degree to which separation, labeling, and stereotyping mediate the association between the learning disability designation and adolescents' math course attainment

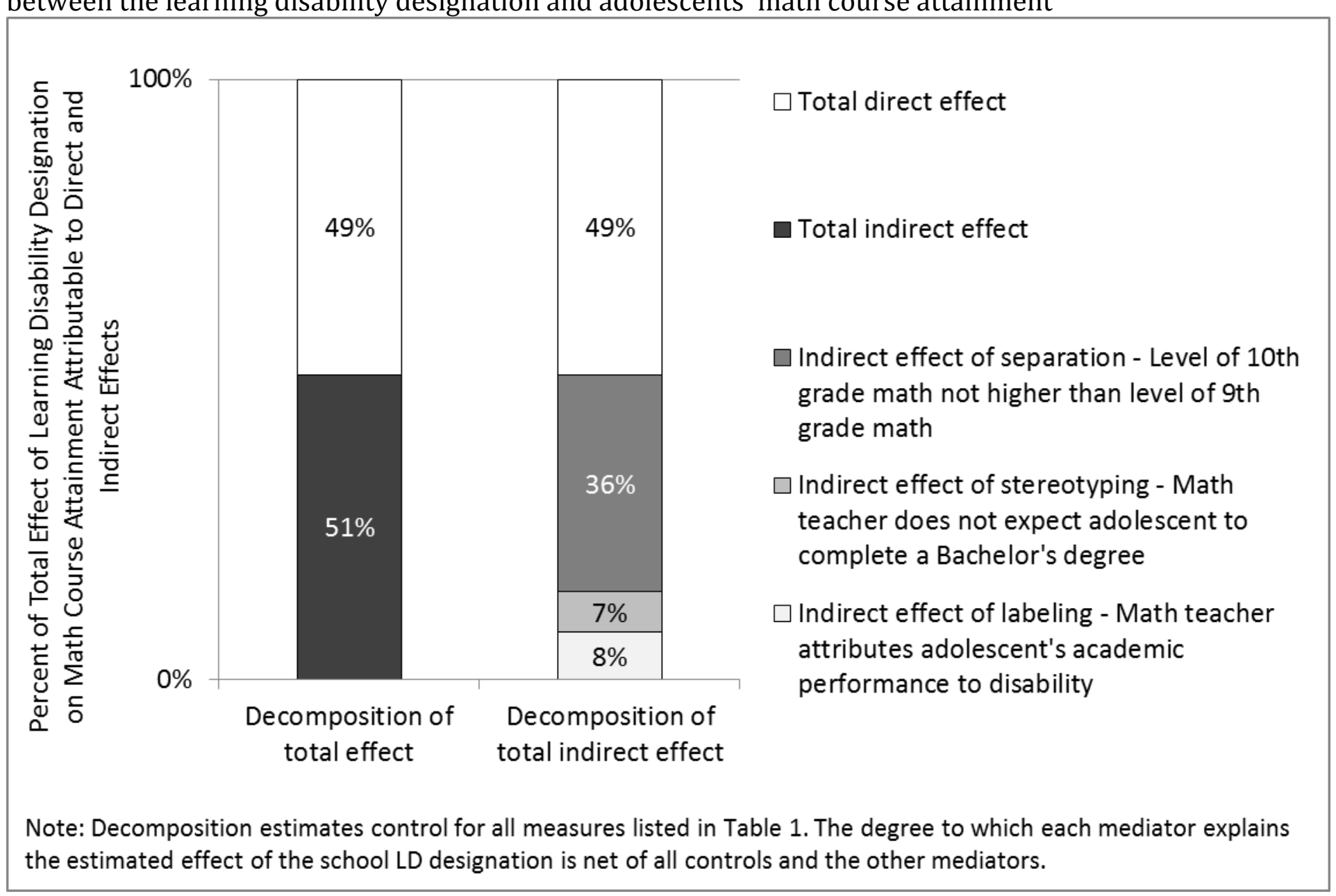


Online Table 1, Part 1 of 2: Sensitivity Analyses - Descriptive Statistics Comparing Analytic Sample to Excluded Cases

\begin{tabular}{|c|c|c|c|}
\hline & $\begin{array}{l}\text { Analytic } \\
\text { sample }\end{array}$ & $\begin{array}{c}\text { Excluded } \\
\text { cases }\end{array}$ & \\
\hline \multicolumn{4}{|l|}{ DEPENDENT VARIABLE } \\
\hline Highest math course attempted by end of high school: & & & $* * *$ \\
\hline Lower than Algebra I & 0.08 & 0.07 & \\
\hline Algebra I & 0.09 & 0.09 & \\
\hline Geometry & 0.14 & 0.13 & \\
\hline Algebra II & 0.22 & 0.21 & \\
\hline Higher than Algebra II & 0.46 & 0.50 & \\
\hline \multicolumn{4}{|l|}{ MEDIATORS POTENTIALLY INDICATIVE OF STIGMA } \\
\hline $\begin{array}{l}\text { Labeling - Math teacher attributes } \\
\text { adolescent's academic performance to disability }\end{array}$ & 0.12 & 0.13 & $* * *$ \\
\hline $\begin{array}{l}\text { Stereotyping - Math teacher expects } \\
\text { adolescent to complete at least Bachelor's degree }\end{array}$ & 0.50 & 0.52 & $* * *$ \\
\hline $\begin{array}{l}\text { Separation - Level of } 10 \text { th grade math } \\
\text { higher than level of } 9 \text { th grade math }\end{array}$ & 0.73 & 0.74 & $*$ \\
\hline \multicolumn{4}{|l|}{ CONTROLS } \\
\hline \multicolumn{4}{|l|}{ Social \& Academic Background } \\
\hline Male & 0.50 & 0.50 & \\
\hline Race: & & & $* * *$ \\
\hline White & 0.62 & 0.52 & \\
\hline Black & 0.13 & 0.18 & \\
\hline Hispanic & 0.16 & 0.18 & \\
\hline Asian & 0.03 & 0.07 & \\
\hline Other race & 0.05 & 0.05 & \\
\hline Socioeconomic status & 0.03 & 0.11 & $* * *$ \\
\hline Cognitive resources in household & 3.87 & 3.93 & $* * *$ \\
\hline Both biological parents live in household & 0.58 & 0.59 & \\
\hline Number of siblings & 2.33 & 2.29 & $* *$ \\
\hline $\begin{array}{l}\text { Parent's educational expectations for } \\
\text { 10th grader }\end{array}$ & 4.90 & 5.12 & $* * *$ \\
\hline Ever in remedial math & 0.10 & 0.10 & \\
\hline Ever in remedial English & 0.08 & 0.09 & $* * *$ \\
\hline Ever retained a grade & 0.13 & 0.11 & $* * *$ \\
\hline Age at 10th grade survey & 15.87 & 15.80 & $* * *$ \\
\hline
\end{tabular}


Online Table 1, Part 2 of 2: Sensitivity Analyses - Descriptive Statistics

Comparing Analytic Sample to Excluded Cases

\begin{tabular}{|c|c|c|c|}
\hline \multirow[b]{2}{*}{ Performance in and Attitudes Toward Math } & $\begin{array}{c}\text { Analytic } \\
\text { sample }\end{array}$ & $\begin{array}{c}\text { Excluded } \\
\text { cases }\end{array}$ & \\
\hline & \multirow[b]{2}{*}{15.53} & \multirow[b]{2}{*}{15.82} & \multirow[b]{2}{*}{$* * *$} \\
\hline Positive attitudes toward math coursework as 10th grader & & & \\
\hline Negative academic behaviors per 10th grade math teacher & 3.33 & 3.27 & $*$ \\
\hline Level of 9th grade math & 1.90 & 1.98 & $* * *$ \\
\hline GPA in 9th grade math courses & 2.44 & 2.50 & $* * *$ \\
\hline Semesters of 9th grade math coursework failed & 0.17 & 0.54 & $* * *$ \\
\hline GPA in 10th grade math courses & 2.30 & 2.34 & $* * *$ \\
\hline Semesters of 10th grade math coursework failed & 0.22 & 0.22 & \\
\hline Score on 10th grade math test & 50.84 & 51.37 & $* * *$ \\
\hline General Academic Attitudes and Behaviors & & & \\
\hline Negative behaviors per 10th grader & 6.73 & 6.82 & $*$ \\
\hline Negative social behaviors per 10th grade teachers & 5.40 & 5.21 & $* * *$ \\
\hline 10th grader's positive attitudes toward learning & 21.05 & 21.73 & $* * *$ \\
\hline 10th grader's educational expectations & 5.14 & 5.29 & $* * *$ \\
\hline Dropped out after 10th grade & 0.05 & 0.04 & $*$ \\
\hline Students (n) & 10,790 & 3,750 & \\
\hline
\end{tabular}


Online Table 2, Part 1 of 2: Multi-Group Analysis of Factorial Structures and Loadings of Attitudinal/Behavioral Scales

$\frac{\text { First Factor }}{\text { No LD LD Diff. No LD LD Diff. }}$

Negative academic behaviors per 10th grade math teacher

Students usually works hard for good grades

$0.770 .75-0.02$

$\begin{array}{lll}0.38 & 0.39 & 0.01\end{array}$

Spoke to parents about poor performance

$\begin{array}{lll}0.70 & 0.70 & 0.00\end{array}$

$\begin{array}{lll}0.37 & 0.37 & 0.00\end{array}$

Spoke to parents about not doing homework

$\begin{array}{llll}0.73 & 0.73 & 0.01\end{array}$

$\begin{array}{llll}0.37 & 0.35 & -0.02\end{array}$

Student behind due to lack of effort

$0.77 \quad 0.73-0.04$

$\begin{array}{lll}0.39 & 0.44 & 0.05\end{array}$

How often student completes homework

$0.810 .77-0.04$

$\begin{array}{lll}0.30 & 0.37 & 0.07\end{array}$

How often student is attentive in class

$\begin{array}{lll}0.72 & 0.71 & 0.00\end{array}$

$\begin{array}{lll}0.43 & 0.45 & 0.02\end{array}$

Spoke to counselor about poor performance

$\begin{array}{lll}0.58 & 0.62 & 0.04\end{array}$

$\begin{array}{llll}0.65 & 0.61 & -0.04\end{array}$

Negative social behaviors per 10th grade teachers

Student relates well to others (math)

Student relates well to others (English)

$\begin{array}{llllll}0.21 & 0.17 & -0.03 & 0.85 & 0.76 & -0.09\end{array}$

$\begin{array}{lllllll}0.23 & 0.25 & 0.02 & 0.83 & 0.72 & -0.11\end{array}$

Spoke to parents about disruptive behavior (math)

Spoke to parents about absenteeism (math)

$\begin{array}{lll}0.56 & 0.68 & 0.12\end{array}$

$\mathbf{0 . 5 0} \mathbf{0 . 3 4}-\mathbf{- 0 . 1 6}$

Spoke to parents about disruptive behavior (English)

$0.360 .35-0.01$

$0.73 \quad 0.65-0.07$

Spoke to parents about absenteeism (English)

$0.550 .60 \quad 0.04$

$0.53 \quad 0.49-0.04$

Student behind due to disciplinary action (math)

Student behind due to disciplinary action (English)

$0.290 .44 \quad 0.16$

$0.76 \quad 0.59-0.17$

$\begin{array}{lll}0.43 & 0.52 & 0.09\end{array}$

$0.73 \quad 0.66-0.07$

$0.47 \quad 0.44-0.03$

$\begin{array}{llll}0.69 & 0.70 & 0.02\end{array}$

How often student is absent (math)

$0.42 \quad 0.36-0.06$

$0.600 .53-0.08$

How often student is tardy (math)

$\begin{array}{lll}0.53 \quad 0.45 & -0.07\end{array}$

$\begin{array}{lll}0.60 & 0.64 \quad 0.04\end{array}$

How often students is disruptive in class (math)

$\begin{array}{lll}0.62 & 0.70 & 0.08\end{array}$

$0.450 .36-0.09$

How often student is absent (English)

How often student is tardy (English)

$0.410 .35-0.06$

$0.610 .57-0.04$

$0.510 .48-0.03$

$\begin{array}{lll}0.60 & 0.62 & 0.02\end{array}$

How often students is disruptive in class (English)

$\begin{array}{lll}0.60 & 0.65 & 0.04\end{array}$

$0.490 .40-0.09$

Spoke to counselor about disruptive behavior (math)

$0.610 .64 \quad 0.03$

$0.46 \quad 0.32-0.14$

Spoke to counselor about disruptive behavior (English)

$\begin{array}{lll}0.58 & 0.65 & 0.06\end{array}$

$0.490 .39-0.10$

\section{Positive attitudes toward math coursework as 10th grader}

Gets totally absorbed in mathematics

$\begin{array}{llllll}0.46 & 0.15 & -0.32 & 0.64 & 0.84 & 0.19\end{array}$

Thinks math is fun

$\begin{array}{llllll}0.65 & 0.47 & -0.18 & 0.35 & 0.45 & 0.11\end{array}$

Mathematics is important

Most people can learn to be good at math

$\begin{array}{lllllll}0.61 & 0.40 & -0.21 & 0.40 & 0.45 & 0.05\end{array}$

Do not have to be born with ability to be good at math

Can do excellent job on math tests

$\begin{array}{llllll}0.37 & 0.23 & -0.13 & 0.66 & 0.78 & 0.12\end{array}$

$\begin{array}{lllllllll}0.14 & 0.01 & -0.13 & 0.77 & 0.85 & 0.08\end{array}$

Can understand difficult math texts

$0.810 .69-0.13$

$\begin{array}{lll}0.28 & 0.43 & 0.15\end{array}$

$0.82 \quad 0.72-0.10$

$\begin{array}{lll}0.26 & 0.38 & 0.12\end{array}$

Can understand difficult math class

$0.85 \quad 0.76-0.10$

$\begin{array}{lll}0.24 & 0.39 & 0.15\end{array}$

Can do excellent job on math assignments

$0.85 \quad 0.77-0.08$

$\begin{array}{llll}0.22 & 0.34 & 0.12\end{array}$

Can master math class skills

$\begin{array}{llll}0.84 & 0.78 & -0.06\end{array}$

\begin{tabular}{lll}
0.23 & 0.34 & 0.11 \\
\hline
\end{tabular} 
Online Table 2, Part 2 of 2: Multi-Group Analysis of Factorial Structures and Loadings of Attitudinal/Behavioral Scales

$\frac{\text { First Factor }}{\text { No LD LD Diff. No LD LD Diff. }}$

10th grader's positive attitudes toward learning

Studies to get a good grade

Can learn something really hard

Remembers most important things when studies

Studies to increase job opportunities

Works as hard as possible when studies

Can get no bad grades if decides to

Keeps studying even if material is difficult

Studies to ensure financial security

Can get no problems wrong if decides to

Does best to learn what studies

Can learn something well if wants to

Puts forth best effort when studying

Negative behaviors per 10th grader

How often forgets paper/pencil

How often forgets books

How often forgets to have done homework

How many times late for school

How many times cut/skip classes

How many times absent from school

How many times got in trouble

How many times put on in-school suspension

How many times suspended/put on probation

How many times transferred for disciplinary reasons;

\begin{tabular}{|c|c|c|c|}
\hline 0.690 .67 & -0.02 & 0.410 .46 & 0.05 \\
\hline $\begin{array}{lll}0.66 & 0.72\end{array}$ & 0.07 & 0.480 .41 & -0.07 \\
\hline 0.740 .77 & 0.03 & 0.420 .33 & -0.09 \\
\hline 0.720 .80 & 0.08 & 0.320 .26 & -0.05 \\
\hline 0.740 .81 & 0.07 & 0.340 .29 & -0.05 \\
\hline 0.680 .68 & 0.00 & 0.440 .45 & 0.00 \\
\hline $0.78 \quad 0.81$ & 0.02 & 0.360 .32 & -0.04 \\
\hline 0.750 .80 & 0.05 & 0.340 .35 & 0.01 \\
\hline $0.65 \quad 0.72$ & 0.08 & 0.480 .41 & -0.07 \\
\hline 0.810 .78 & -0.03 & 0.320 .31 & -0.01 \\
\hline 0.74 & 0.03 & 0.340 .35 & 0.02 \\
\hline 0.750 .80 & 0.05 & 0.340 & -0.08 \\
\hline 0.52 & -0.07 & 0.4 & -0.09 \\
\hline 0.5 & -0.06 & 0.390 .32 & -0.07 \\
\hline 0.48 & -0.12 & $\begin{array}{lll}0.57 & 0.54\end{array}$ & -0.02 \\
\hline 0.49 & 0.02 & 0.620 .59 & -0.03 \\
\hline 0.540 .55 & 0.02 & 0.630 .58 & -0.05 \\
\hline $\begin{array}{lll}0.36 & 0.37\end{array}$ & 0.01 & 0.760 .74 & -0.03 \\
\hline 0.570 .68 & 0.11 & 0.630 .45 & -0.17 \\
\hline 0.540 .62 & 0.08 & 0.570 .4 & -0.09 \\
\hline 0.510 .59 & 0.08 & 0.550 .48 & -0.06 \\
\hline 0.320 .30 & -0.03 & 0.710 .8 & 0.10 \\
\hline
\end{tabular}

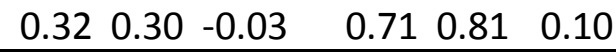

Note: $\mathrm{LD}=$ learning disability. Diff.=difference. Bolded text are scales; factors used to construct each scale listed below. Bolded values are large relative to the other values in the table.

a - The uniqueness represents the percentage of variance for the variable not explained by common factors. 
Online Table 3: Multi-Group Analysis of Attitudinal/Behavioral Scales

\begin{tabular}{|c|c|c|c|c|c|c|}
\hline & \multicolumn{2}{|c|}{ Cronbach's Alpha } & \multirow[t]{2}{*}{ Minimum } & \multirow[t]{2}{*}{ Maximum } & \multicolumn{2}{|c|}{ Standard Deviation } \\
\hline & No LD & LD & & & No LD & LD \\
\hline $\begin{array}{l}\text { Positive attitudes toward math } \\
\text { coursework as } 10 \text { th grader }\end{array}$ & 0.87 & 0.74 & 0 & 30 & 6.60 & 6.50 \\
\hline $\begin{array}{l}\text { Negative academic behaviors } \\
\text { per 10th grade math teacher }\end{array}$ & 0.85 & 0.85 & 0 & 13 & 3.25 & 3.65 \\
\hline $\begin{array}{l}\text { Negative behaviors per 10th } \\
\text { grader }\end{array}$ & 0.71 & 0.74 & 0 & 37 & 4.63 & 6.32 \\
\hline $\begin{array}{l}\text { Negative social behaviors per } \\
\text { 10th grade teachers }\end{array}$ & 0.76 & 0.79 & 0 & 29 & 3.88 & 5.33 \\
\hline $\begin{array}{l}\text { 10th grader's positive attitudes } \\
\text { toward learning }\end{array}$ & 0.93 & 0.94 & 0 & 36 & 9.13 & 10.06 \\
\hline $\begin{array}{l}\text { 10th grader's educational } \\
\text { expectations }\end{array}$ & $\begin{array}{c}\text { not } \\
\text { applicable }\end{array}$ & $\begin{array}{c}\text { not } \\
\text { applicable }\end{array}$ & 1 & 7 & 1.43 & 1.95 \\
\hline
\end{tabular}

Note: LD=learning disability. 
Online Table 4: Multi-Group Analysis of Relationship Between Attitudinal/Behavioral Scales and Math Course Attainment

\begin{tabular}{|c|c|c|c|c|c|c|c|c|c|}
\hline & \multicolumn{4}{|c|}{ No designation } & \multicolumn{5}{|c|}{ Learning disability designation } \\
\hline & B $\quad(S E)$ & $\begin{array}{l}\text { Psuedo } \\
\text { R2 }\end{array}$ & $\begin{array}{l}\text { Pearson's } \\
\text { Chi-square }\end{array}$ & $\begin{array}{l}\text { Hosmer- } \\
\text { Lemeshow } \\
\text { Chi-square }\end{array}$ & B & (SE) & $\begin{array}{l}\text { Psuedo } \\
\text { R2 }\end{array}$ & $\begin{array}{l}\text { Pearson's } \\
\text { Chi-square }\end{array}$ & $\begin{array}{l}\text { Hosmer- } \\
\text { Lemeshow } \\
\text { Chi-square }\end{array}$ \\
\hline $\begin{array}{l}\text { Positive attitudes toward math } \\
\text { coursework as } 10 \text { th grader }\end{array}$ & $0.06(0.00)$ & 0.02 & 67.1 & 47.3 & 0.0 & $(0.02)$ & 0.01 & 26.2 & 12.5 \\
\hline $\begin{array}{l}\text { Negative academic behaviors } \\
\text { per 10th grade math teacher }\end{array}$ & $-0.25(0.01)$ & 0.10 & 56.1 & 50.9 & -0.1 & $(0.04)$ & 0.02 & 5.4 & 1.8 \\
\hline $\begin{array}{l}\text { Negative behaviors per 10th } \\
\text { grader }\end{array}$ & $-0.14(0.01)$ & 0.06 & 58.9 & 26.0 & -0.0 & $(0.02)$ & 0.00 & 17.9 & 2.2 \\
\hline $\begin{array}{l}\text { Negative social behaviors per } \\
\text { 10th grade teachers }\end{array}$ & $-0.18(0.01)$ & 0.07 & 88.8 & 33.8 & -0.1 & $(0.16)$ & 0.05 & 9.6 & 3.0 \\
\hline $\begin{array}{l}\text { 10th grader's positive } \\
\text { attitudes toward learning }\end{array}$ & $0.06(0.00)$ & 0.05 & 71.4 & 31.5 & 0.0 & $(0.01)$ & 0.02 & 0.6 & 0.8 \\
\hline $\begin{array}{l}\text { 10th grader's educational } \\
\text { expectations }\end{array}$ & $0.62(0.02)$ & 0.12 & 65.1 & 30.9 & 0.3 & $(0.07)$ & 0.05 & 4.0 & 3.2 \\
\hline
\end{tabular}

Note: Models include no other predictors excepting the attitudinal/behavioral scale of interest. 
Online Table 5, Part 1 of 3: Log Odds from Ordered Logistic Regression Models Predicting Highest Math Class

Attempted by End of High School (predicted probabilities in Figure 1 estimated from Models A1 and A2 - Models B1, B1, $B 2, C 1, C 2, D 1$, and $D 2$ are sensitvity analyses)

\begin{tabular}{|c|c|c|c|c|c|c|c|c|c|c|c|c|}
\hline & \multicolumn{12}{|c|}{ Adolescents in schools that reported the special education status of... } \\
\hline & \multicolumn{3}{|c|}{$\begin{array}{c}\ldots \text { all or some } \\
\text { sampled students } \\
(n=10,790)\end{array}$} & \multicolumn{3}{|c|}{$\begin{array}{c}\ldots \text { all sampled } \\
\text { students } \\
(n=3,180)\end{array}$} & \multicolumn{3}{|c|}{$\begin{array}{c}\text {.. some sampled } \\
\text { students } \\
(n=7,610)\end{array}$} & \multicolumn{3}{|c|}{$\begin{array}{c}\ldots \text { all, some, or no } \\
\text { sampled students } \\
(n=14,540)\end{array}$} \\
\hline & $\mathrm{B}$ & & (SE) & $\mathrm{B}$ & & (SE) & $\mathrm{B}$ & & (SE) & $\mathrm{B}$ & & (SE) \\
\hline & \multicolumn{3}{|c|}{ Model A1 } & \multicolumn{3}{|c|}{ Model B1 } & \multicolumn{3}{|c|}{ Model C1 } & \multicolumn{3}{|c|}{ Model D1 } \\
\hline Learning disability designation & -2.16 & $* * *$ & $(0.10)$ & -2.42 & $* * *$ & $(0.19)$ & -2.05 & $* * *$ & $(0.12)$ & -2.17 & $* * *$ & $(0.10)$ \\
\hline Cut point 1 & -2.80 & $* * *$ & $(0.10)$ & -2.94 & $* * *$ & $(0.18)$ & -2.75 & $* * *$ & $(0.12)$ & -2.81 & $* * *$ & (0.09) \\
\hline Cut point 2 & -1.87 & $* * *$ & $(0.06)$ & -2.01 & $* * *$ & $(0.12)$ & -1.82 & $* * *$ & $(0.07)$ & -1.88 & $* * *$ & $(0.06)$ \\
\hline Cut point 3 & -1.03 & $* * *$ & $(0.05)$ & -1.13 & $* * *$ & $(0.08)$ & -0.99 & $* * *$ & $(0.06)$ & -1.06 & $* * *$ & $(0.04)$ \\
\hline Cut point 4 & -0.04 & & $(0.04)$ & -0.09 & & $(0.07)$ & -0.02 & & $(0.05)$ & -0.09 & $*$ & $(0.04)$ \\
\hline \multirow[t]{2}{*}{ Bayesian information criterion } & \multicolumn{3}{|c|}{28484.1} & \multicolumn{3}{|c|}{8229.1} & \multicolumn{3}{|c|}{20282.3} & \multicolumn{3}{|c|}{37859.0} \\
\hline & \multicolumn{3}{|c|}{ Model A2 } & \multicolumn{3}{|c|}{ Model B2 } & \multicolumn{3}{|c|}{ Model C2 } & \multicolumn{3}{|c|}{ Model D2 } \\
\hline Learning disability designation & -0.86 & $* * *$ & $(0.11)$ & -1.02 & $* * *$ & $(0.19)$ & -0.78 & $* * *$ & $(0.13)$ & -0.90 & $* * *$ & $(0.11)$ \\
\hline \multicolumn{13}{|l|}{ Social and Academic Background } \\
\hline Male & 0.07 & & $(0.05)$ & -0.09 & & $(0.10)$ & 0.14 & $*$ & $(0.06)$ & 0.07 & & $(0.04)$ \\
\hline \multicolumn{13}{|l|}{ Race: } \\
\hline White (ref) & - & & & - & & & - & & & - & & \\
\hline Black & 0.59 & $* * *$ & $(0.10)$ & 0.60 & $* *$ & $(0.17)$ & 0.61 & $* * *$ & $(0.13)$ & 0.64 & $* * *$ & $(0.09)$ \\
\hline Hispanic & 0.09 & & $(0.08)$ & -0.10 & & $(0.21)$ & 0.15 & + & $(0.09)$ & 0.15 & $*$ & $(0.07)$ \\
\hline Asian & 0.48 & $* * *$ & $(0.13)$ & 0.53 & & $(0.37)$ & 0.50 & $* * *$ & $(0.14)$ & 0.46 & $* * *$ & $(0.10)$ \\
\hline Other race & 0.01 & & $(0.10)$ & -0.14 & & (0.19) & 0.08 & & $(0.12)$ & 0.03 & & $(0.09)$ \\
\hline Socioeconomic status & 0.35 & $* * *$ & $(0.04)$ & 0.39 & $* * *$ & $(0.08)$ & 0.33 & $* * *$ & $(0.05)$ & 0.30 & $* * *$ & $(0.04)$ \\
\hline Cognitive resources in household & 0.02 & & $(0.02)$ & 0.05 & & $(0.03)$ & 0.02 & & $(0.02)$ & 0.04 & $*$ & $(0.02)$ \\
\hline
\end{tabular}


Online Table 5, Part 2 of 3: Log Odds from Ordered Logistic Regression Models Predicting Highest Math Class

Attempted by End of High School (predicted probabilities in Figure 1 estimated from Models A1 and A2 - Models B1, B1, $B 2, C 1, C 2, D 1$, and $D 2$ are sensitvity analyses)

\begin{tabular}{|c|c|c|c|c|c|c|c|c|c|c|c|c|}
\hline & \multicolumn{12}{|c|}{ Adolescents in schools that reported the special education status of... } \\
\hline & \multicolumn{3}{|c|}{$\begin{array}{c}\ldots \text { all or some } \\
\text { sampled students } \\
\quad(n=10,790)\end{array}$} & \multicolumn{3}{|c|}{$\begin{array}{c}\cdots \text { all sampled } \\
\text { students } \\
(n=3,180)\end{array}$} & \multicolumn{3}{|c|}{$\begin{array}{c}\ldots \text { some sampled } \\
\text { students } \\
(n=7,610)\end{array}$} & \multicolumn{3}{|c|}{$\begin{array}{c}\text {... all, some, or no } \\
\text { sampled students } \\
(n=14,540)\end{array}$} \\
\hline & B & & (SE) & B & & (SE) & B & & (SE) & $\mathrm{B}$ & & (SE) \\
\hline & \multicolumn{3}{|c|}{ Model A2, cont. } & \multicolumn{3}{|c|}{ Model B2, cont. } & \multicolumn{3}{|c|}{ Model C2, cont. } & \multicolumn{3}{|c|}{ Model D2, cont. } \\
\hline Both biological parents live in household & 0.07 & & $(0.05)$ & 0.06 & & (0.09) & 0.07 & & $(0.05)$ & 0.07 & + & $(0.04)$ \\
\hline Number of siblings & -0.06 & $* *$ & $(0.02)$ & -0.08 & $* *$ & $(0.03)$ & -0.06 & $*$ & $(0.02)$ & -0.06 & $* * *$ & $(0.01)$ \\
\hline $\begin{array}{l}\text { Parent's educational expectations for } \\
\text { 10th grader }\end{array}$ & 0.13 & $* * *$ & $(0.02)$ & 0.14 & $* * *$ & $(0.04)$ & 0.12 & $* * *$ & $(0.02)$ & 0.13 & $* * *$ & $(0.02)$ \\
\hline Ever in remedial math & 0.01 & & $(0.12)$ & 0.05 & & (0.29) & 0.01 & & $(0.14)$ & -0.06 & & $(0.11)$ \\
\hline Ever in remedial English & -0.15 & & $(0.13)$ & 0.06 & & $(0.27)$ & -0.25 & + & $(0.14)$ & -0.02 & & $(0.11)$ \\
\hline Ever retained a grade & 0.00 & & $(0.08)$ & 0.14 & & $(0.16)$ & -0.04 & & $(0.10)$ & -0.05 & & $(0.06)$ \\
\hline Age at 10th grade survey & -0.10 & $*$ & $(0.04)$ & -0.22 & $* *$ & $(0.08)$ & -0.06 & & $(0.05)$ & -0.03 & & $(0.04)$ \\
\hline \multicolumn{13}{|l|}{ Performance in and Attitudes Toward Math } \\
\hline Level of 9th grade math & 1.17 & $* * *$ & $(0.07)$ & 1.28 & $* * *$ & $(0.11)$ & 1.13 & $* * *$ & $(0.09)$ & 1.15 & $* * *$ & $(0.06)$ \\
\hline GPA in 9th grade math courses & 0.26 & $* * *$ & $(0.03)$ & 0.26 & $* * *$ & $(0.06)$ & 0.26 & $* * *$ & $(0.04)$ & 0.27 & $* * *$ & $(0.03)$ \\
\hline $\begin{array}{l}\text { Semesters of 9th grade math coursework } \\
\text { failed }\end{array}$ & -0.16 & $* * *$ & $(0.04)$ & -0.18 & * & $(0.08)$ & -0.15 & $* *$ & $(0.05)$ & -0.14 & $* * *$ & $(0.04)$ \\
\hline GPA in 10th grade math courses & 0.22 & $* * *$ & $(0.04)$ & 0.21 & $* *$ & $(0.07)$ & 0.22 & $* * *$ & $(0.04)$ & 0.24 & $* * *$ & $(0.03)$ \\
\hline $\begin{array}{l}\text { Semesters of 10th grade math coursework } \\
\text { failed }\end{array}$ & 0.02 & & $(0.05)$ & -0.05 & & $(0.08)$ & 0.03 & & $(0.05)$ & 0.04 & & $(0.04)$ \\
\hline Score on 10 th grade math test & 0.05 & $* * *$ & $(0.00)$ & 0.06 & $* * *$ & $(0.01)$ & 0.05 & $* * *$ & $(0.00)$ & 0.05 & $* * *$ & $(0.00)$ \\
\hline $\begin{array}{l}\text { Positive attitudes toward math coursework } \\
\text { as 10th grader }\end{array}$ & 0.00 & & $(0.01)$ & 0.00 & & $(0.01)$ & 0.00 & & $(0.01)$ & 0.00 & & $(0.00)$ \\
\hline
\end{tabular}


Online Table 5, Part 3 of 3: Log Odds from Ordered Logistic Regression Models Predicting Highest Math Class

Attempted by End of High School (predicted probabilities in Figure 1 estimated from Models A1 and A2 - Models B1, B1,

$B 2, C 1, C 2, D 1$, and $D 2$ are sensitvity analyses)

\begin{tabular}{|c|c|c|c|c|c|c|c|c|c|c|c|c|}
\hline \multirow[b]{5}{*}{$\begin{array}{l}\text { Negative academic behaviors per 10th grade } \\
\text { math teacher }\end{array}$} & \multicolumn{12}{|c|}{ Adolescents in schools that reported the special education status of... } \\
\hline & \multicolumn{3}{|c|}{$\begin{array}{c}\ldots \text { all or some } \\
\text { sampled students } \\
(n=10,790)\end{array}$} & \multicolumn{3}{|c|}{$\begin{array}{c}\cdots \text { all sampled } \\
\text { students } \\
(n=3,180)\end{array}$} & \multicolumn{3}{|c|}{$\begin{array}{c}\cdots \text { some sampled } \\
\text { students } \\
(n=7,610)\end{array}$} & \multicolumn{3}{|c|}{$\begin{array}{c}\ldots . \text { all, some, or no } \\
\text { sampled students } \\
(n=14,540)\end{array}$} \\
\hline & $\mathrm{B}$ & & (SE) & $\mathrm{B}$ & & (SE) & $\mathrm{B}$ & & (SE) & $\mathrm{B}$ & & (SE) \\
\hline & \multicolumn{3}{|c|}{ Model A2, cont. } & \multicolumn{3}{|c|}{ Model B2, cont. } & \multicolumn{3}{|c|}{ Model C2, cont. } & \multicolumn{3}{|c|}{ Model D2, cont. } \\
\hline & -0.02 & + & $(0.01)$ & -0.02 & & $(0.02)$ & -0.02 & & $(0.01)$ & -0.02 & $*$ & $(0.01)$ \\
\hline \multicolumn{13}{|l|}{ General Academic Attitudes and Behaviors } \\
\hline Negative behaviors per 10th grader & -0.02 & $* * *$ & $(0.01)$ & -0.01 & & $(0.01)$ & -0.03 & $* * *$ & $(0.01)$ & -0.02 & $* * *$ & $(0.00)$ \\
\hline $\begin{array}{l}\text { Negative social behaviors per 10th grade } \\
\text { teachers }\end{array}$ & -0.05 & $* * *$ & $(0.01)$ & -0.05 & $* * *$ & $(0.01)$ & -0.05 & $* * *$ & $(0.01)$ & -0.04 & $* * *$ & $(0.01)$ \\
\hline $\begin{array}{l}\text { 10th grader's positive attitudes toward } \\
\text { learning }\end{array}$ & 0.02 & $* * *$ & $(0.00)$ & 0.01 & & $(0.01)$ & 0.02 & $* * *$ & $(0.01)$ & 0.02 & $* * *$ & $(0.00)$ \\
\hline 10th grader's educational expectations & 0.14 & $* * *$ & $(0.02)$ & 0.16 & $* * *$ & $(0.04)$ & 0.13 & $* * *$ & $(0.02)$ & 0.14 & $* * *$ & $(0.02)$ \\
\hline Dropped out after 10th grade & -0.49 & $* * *$ & $(0.10)$ & -0.54 & $* *$ & $(0.19)$ & -0.48 & $* * *$ & $(0.11)$ & -0.53 & $* * *$ & $(0.09)$ \\
\hline Cut point 1 & 1.71 & $*$ & $(0.68)$ & -0.11 & & (1.29) & 2.28 & $* *$ & $(0.79)$ & 2.78 & $* * *$ & $(0.64)$ \\
\hline Cut point 2 & 2.99 & $* * *$ & $(0.68)$ & 1.17 & & $(1.28)$ & 3.56 & $* * *$ & $(0.79)$ & 4.04 & $* * *$ & $(0.63)$ \\
\hline Cut point 3 & 4.35 & $* * *$ & $(0.68)$ & 2.59 & $*$ & (1.29) & 4.91 & $* * *$ & $(0.80)$ & 5.37 & $* * *$ & $(0.63)$ \\
\hline Cut point 4 & 6.02 & $* * *$ & $(0.69)$ & 4.36 & $* *$ & $(1.30)$ & 6.54 & $* * *$ & $(0.80)$ & 7.00 & $* * *$ & $(0.63)$ \\
\hline Bayesian information criterion & \multicolumn{3}{|c|}{21874.7} & \multicolumn{3}{|c|}{6384.1} & \multicolumn{3}{|c|}{20282.3} & \multicolumn{3}{|c|}{28984.7} \\
\hline
\end{tabular}

$+p<0.10, * p<0.05, * * p<0.01, * * * p<0.001$ 
Online Table 6, Part 1 of 2: Log Odds from Logistic Regression Models Predicting Early High School Outcomes Potentially Indicative of Stigma (predicted probabilities in

Figure 2 estimated from these models)

\begin{tabular}{|c|c|c|c|c|c|c|c|c|c|}
\hline & \multicolumn{3}{|c|}{$\begin{array}{l}\text { Labeling - Math } \\
\text { teacher attributes } \\
\text { adolescent's } \\
\text { performance to } \\
\text { disability }\end{array}$} & \multicolumn{3}{|c|}{$\begin{array}{l}\text { Stereotyping - } \\
\text { Math teacher } \\
\text { expects } \\
\text { adolescent to } \\
\text { complete at least } \\
\text { Bachelor's degree }\end{array}$} & \multicolumn{3}{|c|}{$\begin{array}{l}\text { Separation - Level } \\
\text { of 10th grade math } \\
\text { higher than level } \\
\text { of 9th grade math }\end{array}$} \\
\hline & B & & (SE) & $\mathrm{B}$ & & (SE) & $\mathrm{B}$ & & (SE) \\
\hline & \multicolumn{3}{|c|}{ Model A1 } & \multicolumn{3}{|c|}{ Model B1 } & \multicolumn{3}{|c|}{ Model C1 } \\
\hline Learning disability designation & 3.20 & $* * *$ & $(0.11)$ & -2.07 & $* * *$ & $(0.12)$ & -0.16 & $* * *$ & $(0.08)$ \\
\hline \multirow[t]{2}{*}{ Intercept } & -2.47 & $* * *$ & $(0.05)$ & 0.21 & $* * *$ & $(0.04)$ & 1.17 & $* * *$ & $(0.06)$ \\
\hline & \multicolumn{3}{|c|}{ Model A2 } & \multicolumn{3}{|c|}{ Model B2 } & \multicolumn{3}{|c|}{ Model C2 } \\
\hline Learning disability designation & 2.49 & $* * *$ & $(0.16)$ & -0.88 & $* * *$ & $(0.17)$ & -1.27 & $* * *$ & $(0.08)$ \\
\hline \multicolumn{10}{|l|}{ Social and Academic Background } \\
\hline Male & 0.10 & & $(0.10)$ & 0.07 & & $(0.06)$ & 0.01 & & $(0.04)$ \\
\hline \multicolumn{10}{|l|}{ Race: } \\
\hline White (ref) & - & & & - & & & - & & \\
\hline Black & -0.22 & & $(0.14)$ & 0.11 & & $(0.10)$ & 0.08 & & $(0.08)$ \\
\hline Hispanic & -0.03 & & $(0.13)$ & 0.27 & $* *$ & $(0.10)$ & 0.03 & & $(0.07)$ \\
\hline Asian & -0.21 & & (0.19) & 0.37 & $*$ & $(0.14)$ & 0.05 & & $(0.09)$ \\
\hline Other race & -0.06 & & $(0.18)$ & 0.07 & & $(0.13)$ & -0.11 & & $(0.09)$ \\
\hline Socioeconomic status & 0.19 & $* *$ & $(0.07)$ & 0.48 & $* * *$ & $(0.05)$ & 0.12 & $* *$ & $(0.04)$ \\
\hline $\begin{array}{l}\text { Cognitive resources in } \\
\text { household }\end{array}$ & 0.02 & & $(0.04)$ & 0.07 & $*$ & $(0.03)$ & 0.04 & + & $(0.02)$ \\
\hline $\begin{array}{l}\text { Both biological parents } \\
\text { live in household }\end{array}$ & 0.03 & & $(0.09)$ & 0.06 & & $(0.06)$ & 0.12 & $*$ & $(0.05)$ \\
\hline Number of siblings & -0.04 & & $(0.04)$ & -0.04 & & $(0.02)$ & -0.03 & & $(0.02)$ \\
\hline $\begin{array}{l}\text { Parent's educational } \\
\text { expectations for } 10 \text { th grader }\end{array}$ & -0.11 & $* *$ & $(0.03)$ & 0.19 & $* * *$ & $(0.03)$ & & & \\
\hline Ever in remedial math & 0.40 & + & $(0.23)$ & -0.10 & & $(0.18)$ & -0.05 & & $(0.13)$ \\
\hline Ever in remedial English & -0.08 & & (0.19) & -0.01 & & $(0.17)$ & -0.13 & & $(0.11)$ \\
\hline Ever retained a grade & 0.25 & + & $(0.13)$ & -0.27 & $*$ & $(0.10)$ & -0.14 & & $(0.08)$ \\
\hline Age at 10th grade survey & 0.08 & & $(0.07)$ & -0.07 & & $(0.05)$ & & & \\
\hline
\end{tabular}


Online Table 6, Part 2 of 2: Log Odds from Logistic Regression Models Predicting Early High School Outcomes Potentially Indicative of Stigma (predicted probabilities in

Figure 2 estimated from these models)

\begin{tabular}{|c|c|c|c|c|c|c|c|c|}
\hline & \multicolumn{3}{|c|}{$\begin{array}{l}\text { Labeling - Math } \\
\text { teacher attributes } \\
\text { adolescent's } \\
\text { performance to } \\
\text { disability }\end{array}$} & \multicolumn{3}{|c|}{$\begin{array}{l}\text { Stereotyping - } \\
\text { Math teacher } \\
\text { expects } \\
\text { adolescent to } \\
\text { complete at least } \\
\text { Bachelor's degree }\end{array}$} & \multicolumn{2}{|c|}{$\begin{array}{l}\text { Separation - Level } \\
\text { of 10th grade math } \\
\text { higher than level } \\
\text { of 9th grade math }\end{array}$} \\
\hline & \multicolumn{2}{|c|}{$\mathrm{B}$} & (SE) & $\mathrm{B}$ & & (SE) & $\mathrm{B}$ & (SE) \\
\hline & \multicolumn{3}{|c|}{ Model A2, cont. } & \multicolumn{3}{|c|}{ Model B2, cont. } & \multicolumn{2}{|c|}{ Model C2, cont. } \\
\hline \multicolumn{9}{|c|}{ Performance in and Attitudes Toward Math } \\
\hline Level of 9th grade math & -0.10 & & $(0.07)$ & 0.23 & $* * *$ & $(0.05)$ & 0.47 & $* * *(0.03)$ \\
\hline $\begin{array}{l}\text { GPA in 9th grade math } \\
\text { courses }\end{array}$ & -0.02 & & $(0.05)$ & 0.37 & $* * *$ & $(0.05)$ & 0.26 & $* * * \quad(0.02)$ \\
\hline $\begin{array}{l}\text { Semesters of } 9 \text { th grade } \\
\text { math coursework failed }\end{array}$ & -0.08 & & $(0.08)$ & 0.00 & & $(0.10)$ & -0.67 & $* * * \quad(0.05)$ \\
\hline Level of 10th grade math & -0.19 & $* *$ & $(0.06)$ & 0.15 & $* *$ & $(0.05)$ & & \\
\hline GPA in 10th grade math courses & -0.02 & & $(0.07)$ & 0.26 & $* * *$ & $(0.05)$ & & \\
\hline $\begin{array}{l}\text { Semesters of } 10 \text { th grade math } \\
\text { coursework failed }\end{array}$ & 0.00 & & $(0.06)$ & 0.06 & & $(0.08)$ & & \\
\hline Score on 10th grade math test & -0.05 & $* * *$ & $(0.01)$ & 0.06 & $* * *$ & $(0.00)$ & & \\
\hline $\begin{array}{l}\text { Positive attitudes toward math } \\
\text { coursework as } 10 \text { th grader }\end{array}$ & -0.01 & & $(0.01)$ & 0.02 & $* *$ & $(0.01)$ & & \\
\hline $\begin{array}{l}\text { Negative academic behaviors } \\
\text { per 10th grade math teacher }\end{array}$ & 0.17 & $* * *$ & $(0.02)$ & -0.24 & $* * *$ & $(0.01)$ & & \\
\hline \multicolumn{9}{|c|}{ General Academic Attitudes and Behaviors } \\
\hline $\begin{array}{l}\text { Negative behaviors per 10th } \\
\text { grader }\end{array}$ & 0.00 & & $(0.01)$ & -0.01 & & $(0.01)$ & & \\
\hline $\begin{array}{l}\text { Negative social behaviors per } \\
\text { 10th grade teachers }\end{array}$ & 0.05 & $* * *$ & $(0.01)$ & -0.06 & $* * *$ & $(0.01)$ & & \\
\hline $\begin{array}{l}\text { 10th grader's positive attitudes } \\
\text { toward learning }\end{array}$ & 0.00 & & $(0.01)$ & 0.02 & $* * *$ & $(0.01)$ & & \\
\hline $\begin{array}{l}\text { 10th grader's educational } \\
\text { expectations }\end{array}$ & -0.06 & & $(0.05)$ & 0.09 & $* *$ & $(0.03)$ & & \\
\hline Intercept & -0.88 & & $(1.26)$ & -5.36 & $* * *$ & $(0.86)$ & -0.35 & $(0.14)$ \\
\hline
\end{tabular}

Note: Each model estimated with approximately 10,790 adolescents.

$+p<0.10, * p<0.05, * * p<0.01, * * * p<0.001$. 